\title{
Sedimentary evolution of the continental Early-Middle Triassic Cañizar Formation (Central Spain): Implications for life recovery after the Permian-Triassic crisis
}

\author{
José López-Gómez a,*, Belén Galán-Abellán ${ }^{a}$, Raúl de la Horra ${ }^{a}$, José F. Barrenechea ${ }^{b}$, Alfredo Arche ${ }^{a}$, \\ Sylvie Bourquin ${ }^{c}$, Mariano Marzo ", Marc Durand ${ }^{\text {e }}$ \\ a Instituto de Geociencias (CSIC-UCM), Departamento de Estratigrafia, Facultad de Geologí, Universidad Complutene, C/ José Antonio Novais 2, 28040 Madrid, Spain \\ ${ }^{b}$ Instituto de Geociencias (CSIC-UCM), Dpto de Cristalografia y Mineralogia, Facultad de Geologia, Universidad Complutense, C/ José Antonio Novais 2, 28040 Madrid, Spain \\ ' UMR 6118 (CNRS/INSU), Géosciences Rennes, Université de Rennes 1, Campus de Beaulieu, 35042 Rennes Cedex, France \\ a Departamento d'Estratigrafia, Paleontología $i$ Geosciènces Marines, Facultat de Geologia, Universitat de Barcelona, Zona Universitaria de Pedraibes, O8028 Barcelona, Spain \\ e Science de ia Terre et UMR 7566 "GR2", Université Henri Poincaré-Nancy I, BP 239, F-545506 Vandoeuvre-lés-Nancy Cedes, France
}

\author{
Keywords: \\ Triassic \\ Recovery \\ Crisis \\ PTB \\ Climate \\ Smithian \\ Spathian \\ Anisian
}

\begin{abstract}
A B S T R A C T
The Permian-Triassic transition (P-T) was marked by important geochemical perturbations and the largest known life crisis. Consequences of this event, as oxygen-depleted conditions and the unusual behavior of the carbon cycle, were prolonged during the Early Triassic interval delaying the recovery of life in both terrestrial and marine ecosystems. Studies on Lower Triassic sediments of continental origin, as in the case of Western Europe, are especially problematic due to the scarcity of fossils and absence of precise dating. The Cañizar Fm. is an Early-Middle Triassic unit of continental origin of the SE Iberian Ranges, E Spain. A detailed sedimentary study of this unit allows a shedding of light on some unresolved problems of the continental deposits of this age.

The top of this unit is dated as early Anisian by means of a pollen association, while the age of its base is here estimated as late Smithian or Smithian-Spathian transition. Different facies associations and architectural elements have been defined in this unit. In the western and central parts of the basin, this unit shows sedimentary characteristics of fluvial deposits with locally intercalated aeolian sediments, while in the eastern part there is an alternation of both aeolian and fluvial deposits. Sedimentary structures also indicate changes in the climate conditions, mainly from arid to semiarid. Two marked arid periods when well-preserved aeolian sediments developed during early-middle Spathian and Spathian-Anisian transition. They alternated with two semiarid but more humid periods during the late Spathian and early Anisian. These conditions basically correspond with the general arid and very arid conditions described for central-western European plate during the same period of time. The Ateca-Montalbán High, in the northern border of the study basin, must have represented an important topographic barrier in the western Tethys separating aeolian dominated areas to the $\mathrm{N}$ and $\mathrm{NE}$ from fluvial dominated areas to the south.

The Cañizar Fm. has been subdivided into six members (A-F) separated by seven (1-7) major bounding surfaces (MBS). These surfaces are well recognized laterally over hundred of $\mathrm{km}$ and they represent $10^{4}-10^{5}$ My. MBS-5 is considered to be of late Spathian age and it is a clear indication of tectonic activity, represented by a mild unconformity. This event represents a change in the sedimentary characteristics (reactivation) of the unit and from here to the top of the unit are found the first signals of biotic recovery, represented by tetrapod footprints, plants, roots and bioturbation. All of these characteristics and the estimated age represented by the MBS- 5 event permit this surface to be related to the coeval Hardegsen unconformity of Central-Western Europe. These first signals of biotic recovery can thus be related to an increased oxygen supply due to the new created paleogeographical corridors in the context of this tectonic activity. These biotic signals occurred 5 My after the Permian-Triassic limit crisis; a similar delay as occurred in other coeval and neighboring basins.
\end{abstract}

\section{Introduction}

The time around the Permian-Triassic boundary was marked by a number of anomalous events and the biggest known crisis in life history, which provoked drastic changes in terrestrial and marine ecosystems (e.g. Martin and Macdougall, 1995; Benton, 2003; Erwin, 
2006). The magnitude of many of these events, which included massive volcanism from the Siberian Traps and its consequent general geochemical anomalies, led to multiple environmental perturbations and a series of short- and long-termed changes in ecosystems that first caused a widespread mass mortality event and lately delayed the subsequent Early Triassic recovery (see among others Pruss and Bottjer, 2005; Chen et al., 2007; Bottjer et al., 2008; Hermann et al., 2011).

Large and protracted volcanic episodes may have been a trigger for the continuation of the disturbances of the carbon cycle during the Early Triassic (Baud et al., 1996; Payne and Krump, 2007; Sellwood and Valdes, 2007). In the same way, oxygen-depleted conditions during the Early Triassic have been widely described as a continuation of the perturbations from the Permian-Triassic boundary event in both marine and continental environments (Wignall, 1990; Hallam, 1991; Retallack, 1999; Sheldon and Retallack, 2002; Pruss et al., 2005).

During this latter period and even until the early Anisian, these excursions in the carbon isotope ratios have been related to climate variations (Kidder and Worsley, 2004; Galfetti et al., 2007b), paleoceanographic changes (Atudorei and Baud, 1997; Brüihwiler et al., 2009), rare and episodic sedimentation (Woods et al., 1999; Pruss et al., 2005) and even phosphate regeneration, productivity and related biodiversity (Payne and Krump, 2007).

Although there is a general acceptance concerning connections of multiple perturbations during the Early Triassic with drastic environmental changes and the delay in the post-extinction recovery (Payne et al., 2004), there is still an important lack of information when an attempt is made to establish correlations between the observed marine and continental variations. There are few papers focussed on this problem, and only some of them recognize clear relationships (e.g. Twitchett, 1999; Krull and Retallack, 2000; Galfetti et al., 2007a).

One of the main problems for correlations between marine and continental sediments is to establish a precise age of continental rocks, always difficult but even more so in a period during a biotic crisis that left only a decimated fossil record. Particularly, this fact impedes correlations also between continental series. Some important attempts have been made to tackle this problem in the Early Triassic series of continental origin from Central-Western Europe by means of different dating techniques when fossils were almost absent or poorly representative (e.g. Geluk and Röhling, 1997; Bourquin et al., 2006, 2009; Filomena and Stollhofen, 2011).

The Cañizar Fm. (Early-Middle Triassic) is a very well exposed unit of continental origin in the central-eastern Iberian Range, Central Spain. It shows a similar general lack of biotic data as the above mentioned Early Triassic series of Central-Western Europe and was probably deposited under similar anomalous geochemical conditions. Although there are several works dealing with the Cañizar Fm. (López-Gómez and Arche, 1993a,b; Alonso-Azcárate et al., 1997; Arche and López-Gómez, 1999; 2005; Vargas et al., 2009; LópezGómez et al., 2010), none of these focusses on the relationship between the sedimentary environment, the biotic recovery and its paleogeographical significance. The aim of the present work is to define new approaches on the sedimentary and biotic characteristics and to determine the age of the Cañizar Fm. in order to define precisely its sedimentary environment, the first signals of biotic recovery after the Permian-Triassic transition crisis and its paleogeographical significance in the western Tethys domain.

\section{Geological setting}

At the end of the Permian and Early Triassic Iberia was located in the eastern side of central Pangea. It was a small plate assembled in the southernmost part of the ancient Laurentia megacontinent (De Vicente et al., 2009; Vargas et al., 2009).
The present-day Iberian Range (Fig. 1A, C) is an intracratonic linear alpine structure occupying central and eastern Spain, which was created by inversion tectonics during the Alpine compressive events in an extensional Mesozoic basin: the Iberian Basin (Fig. 1B). The origin of the Iberian Basin was related to the development of a faultbounded multistage rift basin during the Early-Middle Permian (Arche and López-Gómez, 1996; Vargas et al., 2009). This basin started its development on a Hercynian basement of Cambrian-Silurian slates and quartzites affected by low-grade metamorphism, which was deformed in kilometer-size structures trending NW-SE with a general eastwards convergence (Capote and González-Lodeiro, 1983; De Vicente et al., 2009).

The Iberian Range is subdivided into the Castilian and the Aragonian Branches, toward the northeast and the southwest, respectively (Fig. 1B). These are morphological alpine structures hundreds of kilometers long, trending NW-SE and we separated by different Cenozoic basins. These major structures are controlled by basin boundary faults that acted as normal faults during the Mesozoic development of the basin and later were reactivated as reverse faults during the alpine compression. During the evolution of the rift basin, a series of accommodation faults was developed almost perpendicular to the main NW-SE extensional faults which allowed block differentiation during the refilling of the basin.

In the Castilian Branch, the refilling of the Iberian Basin started during the Permian and consists of a well-developed series of alluvial deposits (López-Gómez and Arche, 1993a; Arche and López-Gómez, 1996) (Fig. 2). Above these rocks, and separated from them by an important hiatus, expressed sometimes as an angular unconformity, are the first Triassic deposits, the so-called Buntsandstein facies, of Earlyearly Middle Triassic, which are also of continental origin, mainly fluvial but also of aeolian (Bourquin et al., 2007, 2011; López-Gómez et al., 2011; Soria et al., 2011). These sediments were succeeded during the Anisian-Ladinian times by the deposition of carbonates of shallow marine origin (Muschelkalk facies) related to the westward progradation of the Tethys sea (López-Gómez and Arche, 1993a; LópezGómez et al., 1993, 1998, 2002).

These continental sediments are broadly organized into two main sequences, the lower one for the Permian and the upper one for the Triassic. When the sedimentary record is complete, the Triassic continental sequence is mainly constituted by the Cañizar and Eslida fms., from base to top respectively, and the Valdemeca Unit, that constitutes the lowermost part of the Cañizar Fm. in some areas of the Castilian branch. The present work is focussed on the Cañizar Fm. in the SE of the Castian branch (Fig. 1C) where three main fault-bounded blocks or sub-basins can be differentiated (Fig. 1B). These basins were not isolated during the Triassic from their neighboring ones, however some sedimentary characteristics are particular for each one. Based on these characterisics, the area of the present study is divided in three sectors (Fig. 1B): Western (W) sector (west of the Teruel-Montalbán fault), Central (C) sector (between Teruel-Montalbán and Sagunto-Benicassim faults) and Eastem (E) sector (east of the Sagunto-Benicassim fault).

\section{Stratigraphy and sedimentology of the Cañizar Formation}

\subsection{The stratigraphy}

A total of seven complete sections of the Cañizar Fm. have been studied (Fig. 3). These sections are representative of the W, C and $E$ sectors. Sector $W$ is represented by the Río Mayor, Talayuelas and Puntal del Carnero sections, sector $C$ by the Montán, Gátova and Alfondeguilla sections and sector $C$ is represented by the Benicassim section.

The Cañizar Fm. (López-Gómez and Arche, 1993b) commonly crops-out to form prominent cliffs (Fig. 4). Its thickness ranges from $75 \mathrm{~m}$ to $165 \mathrm{~m}$ and its lateral continuity reaches hundreds of kilometers across the Iberian Ranges, although its name changes 
toward the N and NW of the Iberian Ranges, outside the study area, where it is named the Rillo de Gallo Fm. (Ramos, 1979; López-Gómez et al., 2002, 2005). The Cañizar Fm. lies unconformably on the Alcotas Fm. of Middle Permian age and the contact with the overlying Eslida
Fm., of early Anisian age, is represented by a hiatus surface in most of the study area (Arche and López-Gómez, 2005) (Fig. 2).

The Cañizar Fm. is basically composed of sandstone bodies with thin layers of intercalated mudstone. The texture of the sandstone
A

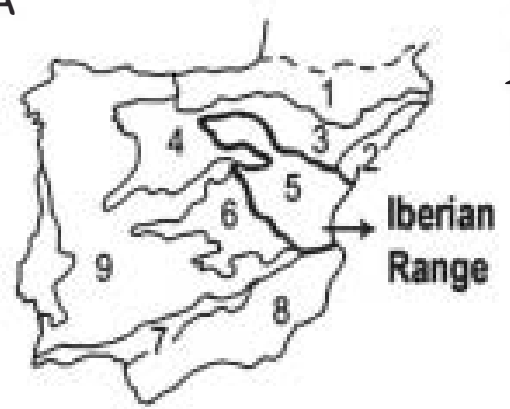

IIIIII Elevated Paleozoic blocks

Main basin boundary faults

PMCL: Present Mediterranean coast line
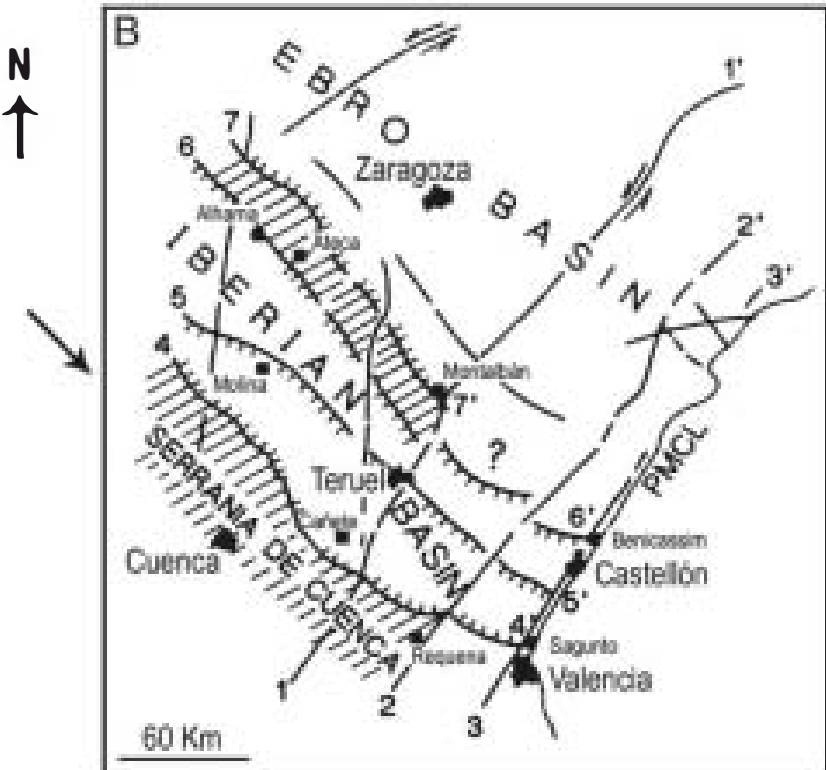

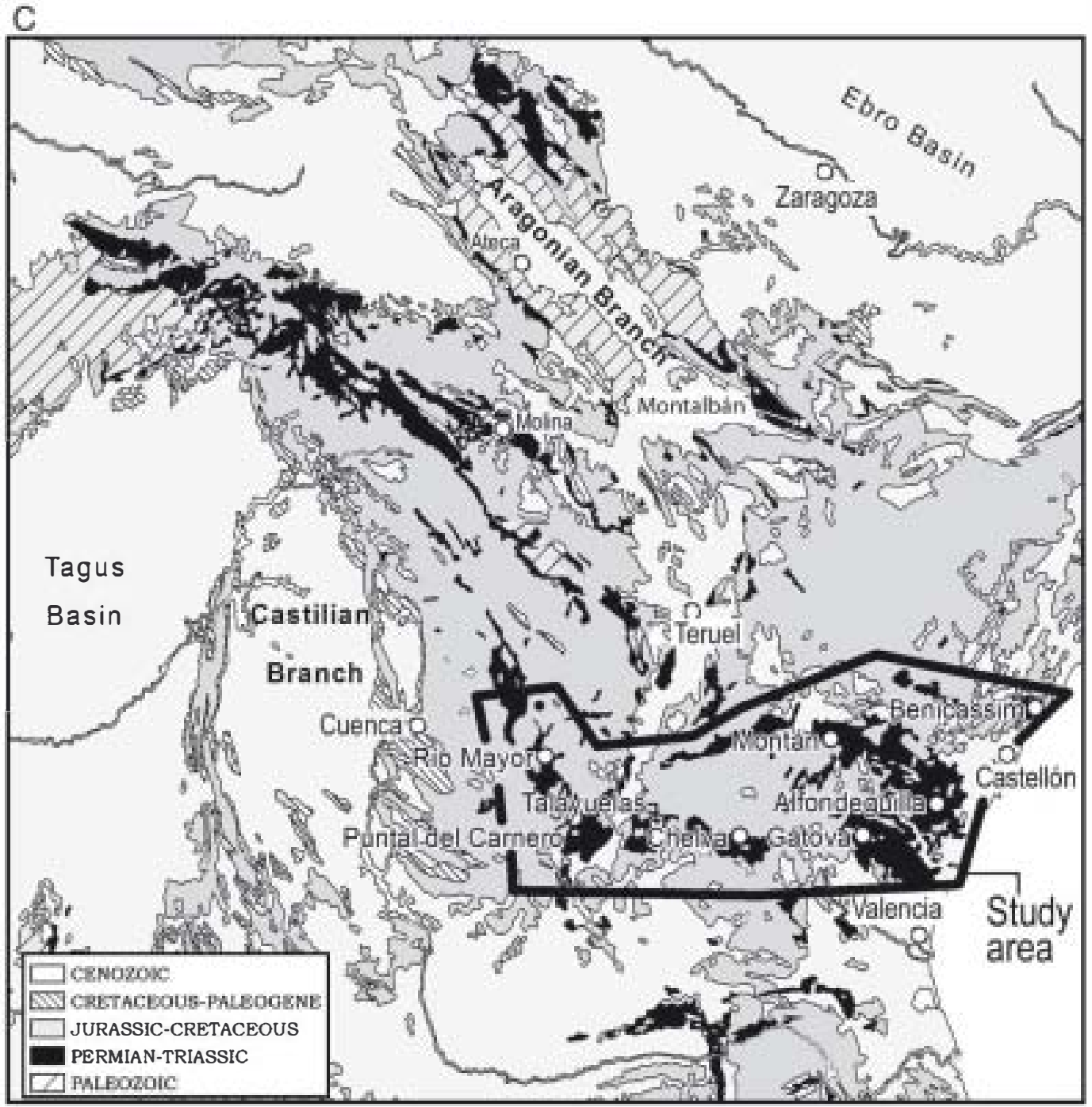


varies from fine to coarse grained and is angular to well-rounded. The general petrological composition changes transitionally from subarkose in the NW to quartz-arenite in the SE (Fig. 5), a change probably related to loss of feldspars during transport from proximal to distal areas, as indicated by paleocurrent data of the fluvial systems, that are mainly directed to the SE and S.SE (Fig. 3); this was parallel to the main axis of the basin, where master faults were still controlling sedimentation (Fig. 1B). Sandy matrix-supported centimeter-thick quartzitic conglomerate levels occur locally.

The Cañizar Fm. consists of six subunits or informal members, A to F (Fig. 3), (López-Gómez and Arche, 1993b). The lowest, which only crops-out in the westem part, was later defined as the Valdemeca Conglomerates unit (De la Horra et al., 2005). This subunit is laterally equivalent to the Chequilla Conglomerates of the NW Iberian Ranges defined by Ramos (1979), out of the area studied in this work. The other five differentiated members are present in most of the studied sections. The six members are delimited by seven ( 1 to 7 ) major bounding surfaces (MBS) that show lateral continuity across the study area, except in the easternmost part, E sector, where these surfaces are not easy to differentiate from the laterally equivalent aeolian sediments. The A to F members and the seven MBS, originally defined for the Cañizar Fm. by López-Gómez and Arche (1993b), are also used in this study with some minor modifications (Figs. 3,4). The internal architecture of members shows also minor bounding surfaces (mbs). Both MBS and mbs will be described later.

\subsection{The sedimentology: facies and architectural elements}

The sedimentary characteristics of the Cañizar Fm. are defined here by means of the analysis of different facies and facies associations that constitute sedimentary bodies or architectural elements (sensu Miall, 1992, 1996) with particular external and internal geometry. The sedimentary environment has been reconsucted from the analysis and interpretation of these architectural elements and bounding surfaces are based on the concepts and nomenclature of Allen (1963), DeCelles et al. (1991), Bridge (1993) and Miall (1995, 1996). The writer's nomenclature is applied in the case of the aeolian sediments.

\subsubsection{Fluvial sediments}

These sediments are the most common in the studied stratigraphic sections and constitute almost the total record in the western and central sectors. A total of 8 facies have been differentiated in the sediments of fluvial origin. These facies consist of three main lithologies: conglomerates $(G)$, sandstones $(S)$ and mainly fine grained mainly sandstones but also with mudstones (F). Different colors and sedimentary and/or biogenic structures are common in these lithologies and define the different facies. These are: planar cross-stratification $(\mathrm{p})$, trough cross-stratification $(\mathrm{t})$, parallel lamination $(\mathrm{h})$, current ripples ( $r$ ), bioturbation (b), plant remains (p) and incipient paleosols. The eight differentiated facies result from the most frequent observed combination of these structures with the three lithologies described above. The description and interpretation of these facies are summarized in Fig. 6.

These facies tend to be organized into 6 facies associations, showing specific vertical succession and thickness and therefore from a characteristic morphology for each. At outcrop these morphologies can be observed in 2D and sometimes in 3D. In this latter case, some other characteristics, such as type of the base and top. The

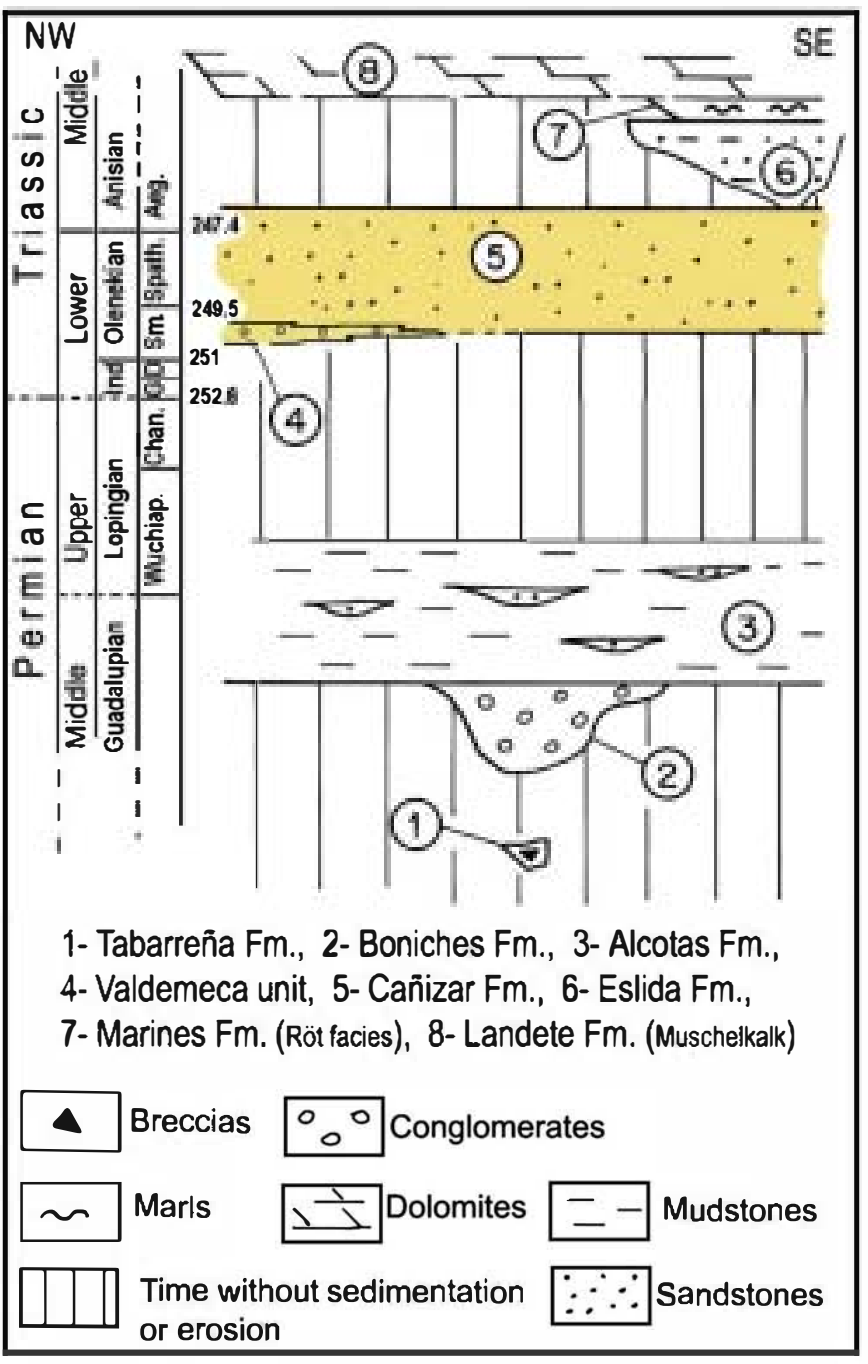

Fig. 2. Scheme of the Permian and Triassic sedimentary successions in the Iberian Ranges including lithological units, unconformities and hiatuses.

predictable type of vertical facies succession of each facies association, their thickness and their particular geometric arrangement define a total of 7 architectural elements in the Cañizar Fm. The description, interpretation and presence of these architectural elements in the different members of each of the W, C, E sectors are summarized in Fig. 7.

The architectural elements include: filled isolated channels with defined borders $(\mathrm{CH})$, sandstone megarripples (mesoforms) with planar or erosive bases ( $\mathrm{SBp}, \mathrm{SBe}$ ), downstream accretion mesoforms (DA), sandy bedforms with isolated clasts (SGB), sandstone bodies with parallel or semi-parallel lamination (LS) and gravel bedform (GB) (Fig. 8). Each member (A to F) of the Cañizar Fm. shows one or more different architectural elements and the presence of these elements in each member also can change laterally from one sector to other of the study area.

Five of the defined architectural elements are related to channel development ( $\mathrm{CH}, \mathrm{SB}, \mathrm{DA}, \mathrm{SGB}, \mathrm{GB})$, while just one (LS) to nonchannelized fluvial deposition.

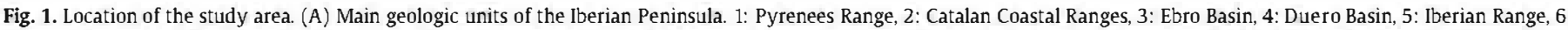

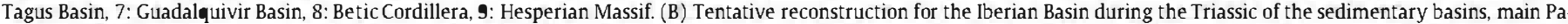

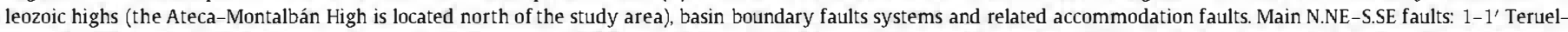

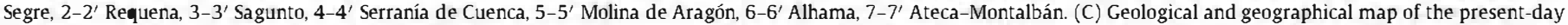

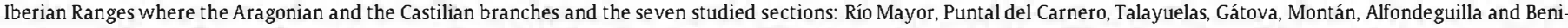

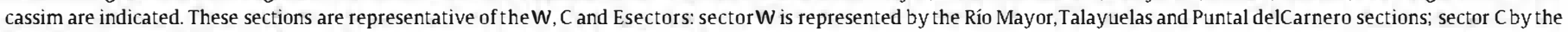
Montán, Gátova and Alfondeguilla sections, and sector $\mathrm{E}$ by the Benicassim section. 


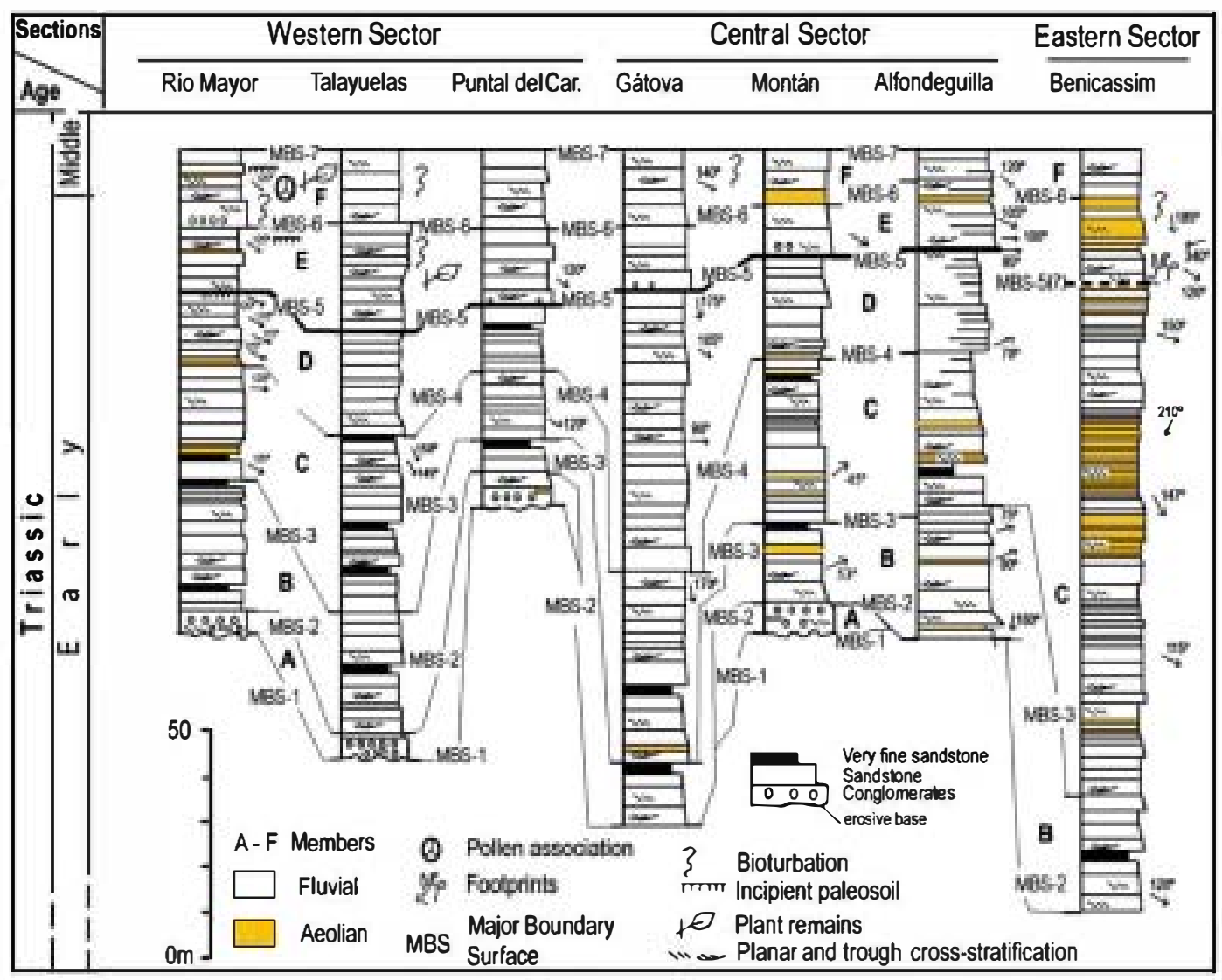

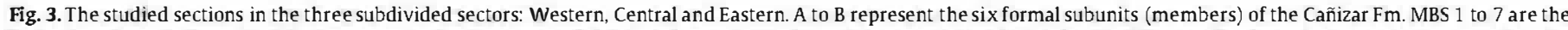

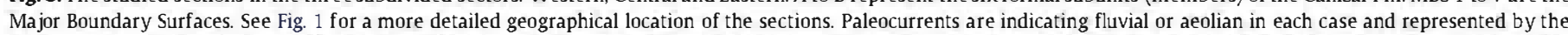

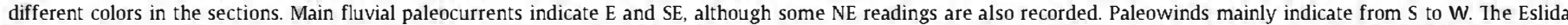

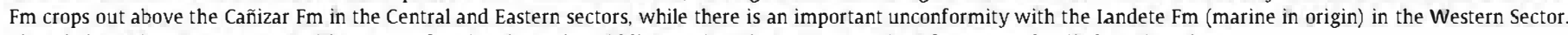
The whole Cañizar Fm crops out with an unconformity above the Middle Permian Alcotas Fm. See Fig. 2 for a more detailed stratigraphy.

Paleocurrents in these fluvial sediments are directed mainly to the $\mathrm{SE}$ and S.SE in all the members and range from $100^{\circ}$ to $170^{\circ} \mathrm{N}$ (LópezGómez and Arche, 1993b), but occasionally some fluvial paleocurrents also indicate transportation to the NE (Fig. 3). These data have been obtained from 83 readings mainly on planar and trough crossstratification but also from parting lineation structures.

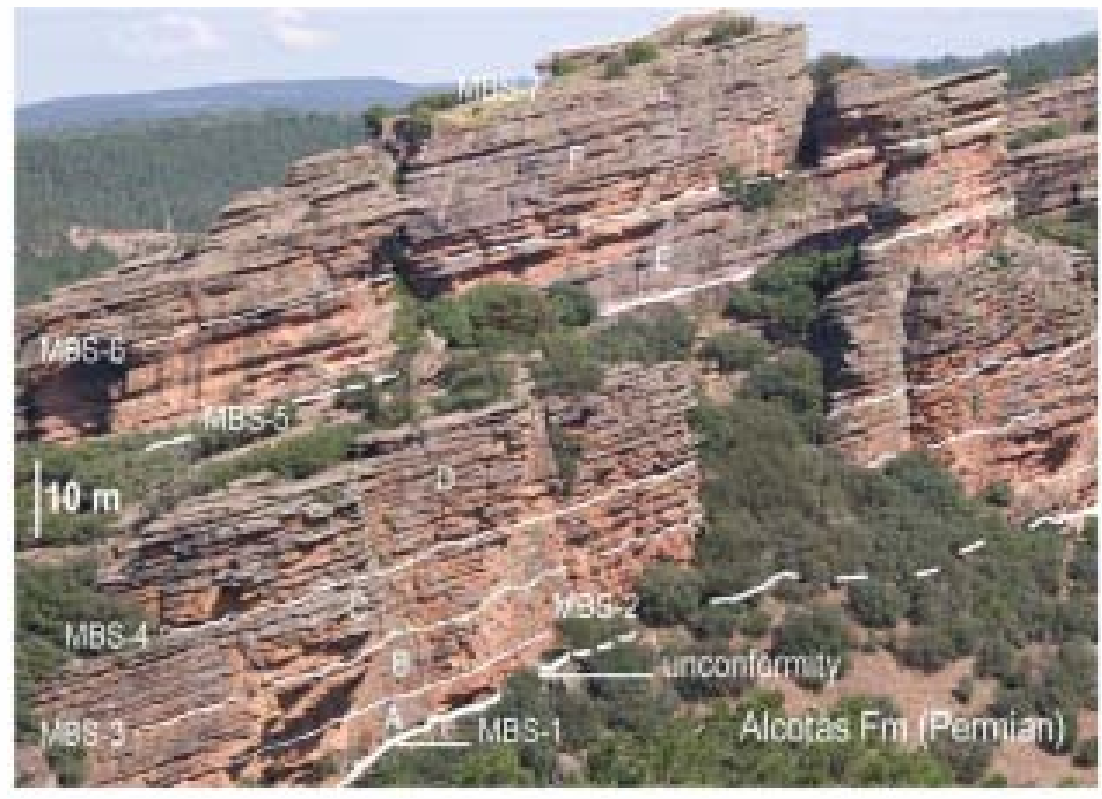

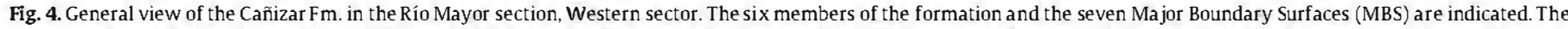

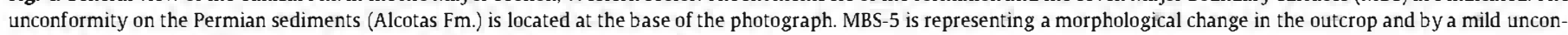
formity in some areas. This surface is commonly shown by a more vegetated cover. 
3.2.1.1. Channel-fil complexes with defined borders ( $\mathrm{CH})$. These have concave-up erosive bases, although these are not commonly well preserved. The width of individual complexes is less than $50 \mathrm{~m}$ and thicknesses rarely exceeds $4 \mathrm{~m}$ (Fig. 8a). They are always amalgamated and are constituted of partially eroded sequences of less than $1 \mathrm{~m}$ in thickness composed of facies St, Sp, Sh, and Sr. This element occurs almost exclusively in $W$ sector, and is mainly related to members $\mathrm{E}$ and $\mathrm{A}$.

These are interpreted as channel-fill sandstone bodies which have deposited during important lateral shifts which have provoked frequent erosive surfaces in the mesoforms that make it difficult to recognize the channel margins (Gibling, 2006). They are related to proximal and medial areas into the fluvial system.

3.2.1.2. Megariples of sandstone complexes (SB). Vertical accumulation of straight and sinuous crest sandstone megaripples commonly appears in the three studied sectors. Their lateral migration has produced erosive surfaces (SBe), although they have often accumulated with planar contacts (SBp). Vertically they are upward fining with sequences which rarely exceeds $1 \mathrm{~m}$ in thickness where facies St, Sp, Sh and $\mathrm{Sr}$ are the most representative. Their vertical accumulation may reach tens of meters (Fig. $8 \mathrm{~b}$ ) and have sheet morphologies. These are common in all of the members and in all the three studied sectors.

These are interpreted as channel-fill deposits which were deposited over wide areas of sedimentation of sand-dominated river systems. They represent trains of individual bedforms that accumulated predominantly by vertical aggradation (Ashley, 1990; Gibling and Rust, 1990).

3.2.1.3. Downstream accretional deposits (DA). These are formed of cosets of downstream-oriented flow-regime bedforms, and normally are common in sector $W$. They are differentiated in large exposures where individual bedforms are formed by planar cross bedding about $1.5 \mathrm{~m}$ to $2.5 \mathrm{~m}$ in thickness. Characteristically they rest on the moderate dipping surfaces of the previous bedform which show a gentle concave-upper surface and may reach tens of meters in width (Fig. 8c).

These are interpreted as dynamically related trains of sanddominated bedforms with vertical aggradation (Miall, 1996) and indicate filling of channels with a more important height in the system which is roughly similar to minimum channel depth.

3.2.1.4. Sandy bedforms with isolated clasts (SBG). These consist of vertical accumulations of straight-crest sandy bedforms that incorporate disperse quartzite subrounded-rounded clasts. The bedforms consist mainly of facies Sp, rarely exceed $1 \mathrm{~m}$ in thickness and show a general fining-upward trend (Fig. 8d). They consist of sets that may reach $3 \mathrm{~m}$. The base and top of bedforms may be flat and may be slightly eroded. This element is very common in both $W$ and $C$ sectors and it is mainly linked to members $\mathrm{E}$ and $\mathrm{A}$.

These deposits are interpreted as channel-fill deposits of migrating streams in a wide area of sedimentation of sandy and gravelydominated river systems. They represent trains of individual bedforms related to stages of increasing energy during periods of reactivation in the system (Ramos et al., 1986).

3.2.1.5. Gravel bedforms (GB). This element is basically represented by facies $P$. It appears only in member $A$ and use to be more frequent in sector $W$. It consists of gravelly bedforms that rarely exceeds $0.7 \mathrm{~m}$ in thickness and forms sets that may reach $8 \mathrm{~m}$ (Fig. 8e). They show subrounded-rounded quartzite clasts less than $8 \mathrm{~cm}$ in size and planar and trough cross-stratification and may incorporate sand lenses of few meters in width which separate the bedforms.

These are interpreted as channel-fill deposits linked to proximalmedial areas with periodical waning-water stages in a shallow gravel dominated fluvial system, similar to the examples described by Ramos and Sopeña (1993) and Rice et al. (2009).

3.2.1.6. Laminated sandstone bodies interbedded with mudstones (LS). This element is basically developed in members $C$ and $D$ but also appears in $C$ and $E$ sectors. It consists of sandy bodies with parallel or semi-parallel lamination and possible current ripples (Fig. 8f) which are interbedded with fine sandstone or mudstones. The sand layers sometimes reach several centimeters in thickness, although locally form sets that may reach $1 \mathrm{~m}$ in thickness. They mainly consist of facies Sh, Sbp, Fl and Fb.

This architectural element is interpreted as a non-channelized deposit related to overbank flooding (Bown and Kraus, 1987; Smith et al., 1989) and it is commonly related both vertically and laterally to channelized elements.

\subsubsection{Boundary surfaces}

Different orders of classifications of bounding surfaces have been erected for alluvial sediments by some authors (Allen, 1983; DeCelles et al., 1991; Bridge, 1993; Miall, 1992, 1996; Bristow and Best, 1993, among others) using different names or numbers, but with clear equivalences among them. We have followed Miall's (1996) classification for the interpretation of the numerical values of the time-span of each major and minor described surface.

Different types of boundaries have been observed in the sediments of the Cañizar Fm. They range from 1 to 8 order according to Miall's (1996) classification and constitute minor and major boundary surfaces (mbs and MBS, respectively) depending on the type of surface they represent. They may range from only the laminae of a ripple to major surfaces affecting the whole basin. In this latter classification, 1 st to 4 rd-order include a range of surfaces related to process of development of a microform (e.g. ripple) to a macroform (e.g. levee, splay or point bar), and each represents less than $10^{3}$ years of development. The 5th order surface includes a channel base surface and represents $10^{3}-10^{4}$ years, while a 6 th order is related to flat, regionally extensive surface (e.g. a channel belt) and represents $10^{4}-$ $10^{5}$ years. The 7 th and 8 th order surfaces are both regionally

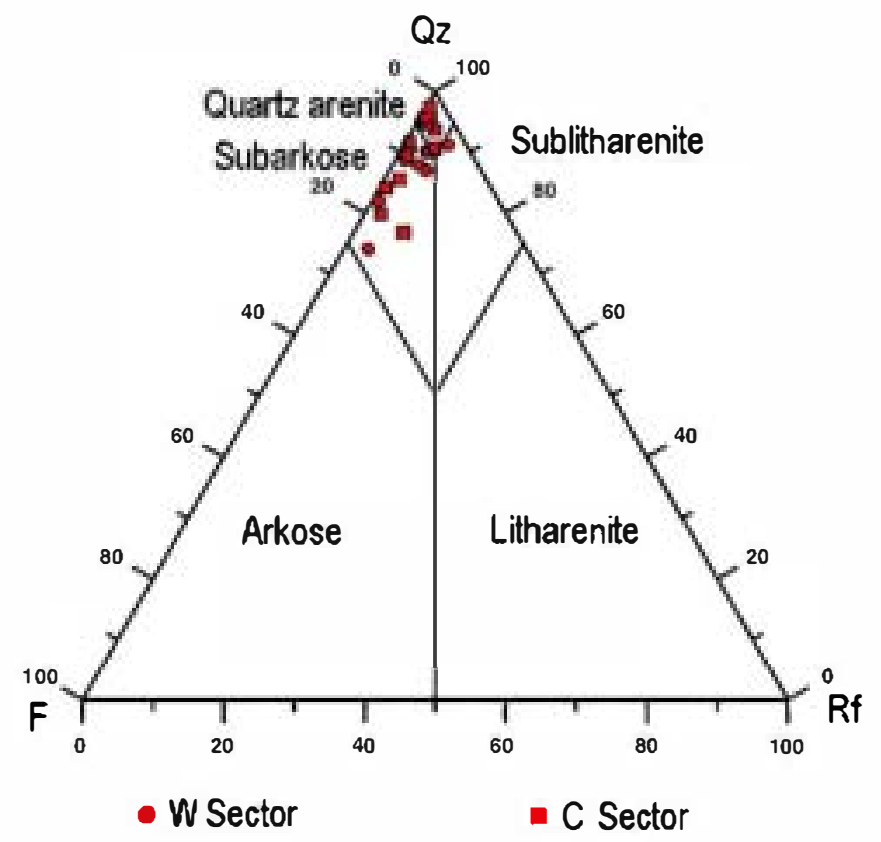

Fig. 5. Triangular (Q-F-R) diagram showing sandstone composition of the Cañizar Fm. in $\mathrm{W}$ and $\mathrm{C}$ sectors, where fluvial sediments are dominant. 


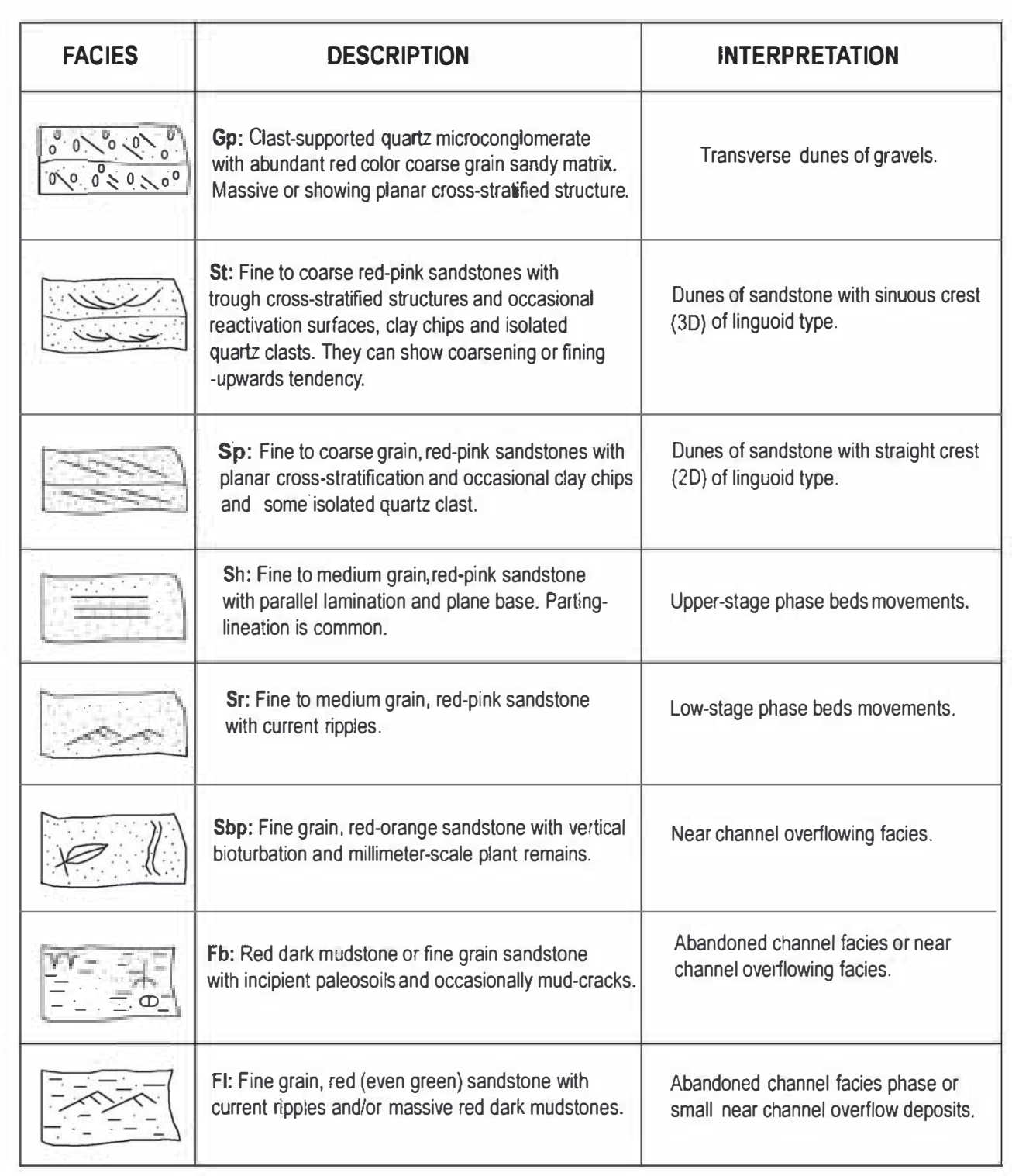

Fig. 6. The eight defined facies and their interpretation for the fluvial sediments of the Cañizar Formation (some of the facies characteristics are obtained from Miall, 1996 classification).

extensive (e.g. major depositional system and basin-fill complex, respectively) and represents $10^{5}-10^{6}$ and $10^{6}-10^{7}$ years respectively.

Surfaces of minor order (mbs) are of 1 st to 5th order, while MBS are represented by those 6 th, 7 th and 8 th order. Fig. 9 shows some differentiated boundaries and illustrates how they fit in Puntal del Carnero section (sector $\mathrm{C}$ ). Minor boundary surfaces are welldefined in the interior of the meso- and macroforms included in the architectural elements. The MBS are however observed as planes that can be followed for hundreds of meters in the outcrops and therefore they are regionally differentiated (Figs. 3, 4). The six members (A-F) of the Cañizar Fm. are separated by surfaces of 6th order, except the surface between members $D$ and $E$ (MBS-5) whose is separated by a 7th order surface. This latter surface, which is associated to a slight unconformity, represents a boundary that separates important sedimentary and lithologic features that can be traced as much as hundreds of kilometers across the studied basin. For what concerns the angular unconformity at the base of the Cañizar Fm. it represents a hiatus likely more than $8 \mathrm{My}$ and separates the Middle-Late Permian from the beginning of the Triassic sedimentation, and this is considered an 8th order surface.
In order to determine the vertical evolution of the Cañizar Fm. it is important to consider both the time of sedimentation and the hiatuses and/or erosion, represented by mbs and MBS. These aspects are discussed later.

\subsubsection{Aeolian sediments}

Aeolian sediments occur mainly in Eastern sector, close to the present-day Mediterranean coast, where they are tens of meters in thickness in the Benicassim section. However, thin isolated aeolian beds, normally lesser than $1 \mathrm{~m}$ in thickness intercalated with sediments of fluvial origin, are also present in sectors Western and Central sectors of the studied area. Although there are some references of aeolian deposits in equivalent units of neighboring areas (Marzo, 1986; Soria et al., 2011), in the study area these deposits are identified and described for the first time. Paleowinds mainly are directed to the $S$ and SW with a range from $175^{\circ}-265^{\circ}$. These are based on 57 readings from what have been interpreted as former avalanching faces of dunes.

Four main facies (ae-1 to ae-4) and eight associated or secondary facies have been differentiated in the aeolian sediments. The 


\begin{tabular}{|c|c|c|c|c|c|c|}
\hline \multicolumn{7}{|c|}{ ARCHITECTURAL ELEMENTS } \\
\hline \multicolumn{3}{|c|}{$\begin{array}{l}\text { Presence of the eiements } \\
\text { in the members }(A-F) \text { of } \\
\text { the three sections (W:CE) } \\
-W-W-C-E-1\end{array}$} & Description & Facies associations & Morphology & $\begin{array}{l}\text { Some other } \\
\text { characteristics }\end{array}$ \\
\hline$E, A$ & & & $\begin{array}{l}\text { CH: Channel - fill complex } \\
\text { with defined borders. }\end{array}$ & ${ }_{0}^{09 m \rightleftharpoons 5}$ & $P \Gamma_{1.7-38 m}$ & $\begin{array}{l}\text { Concave-up } \\
\text { erosional base. } \\
\text { Very common } \\
3^{\text {rd }} \text { order internal } \\
\text { erosional surface. }\end{array}$ \\
\hline $\begin{array}{l}\text { A } \\
\text { A,B,C } \\
\text { D.E.F }\end{array}$ & $\begin{array}{l}A, B \\
A, B, C \\
D, E, F\end{array}$ & $\begin{array}{l}\mathrm{A}, \mathrm{B}, \mathrm{C} \\
\mathrm{F}\end{array}$ & $\begin{array}{l}\text { SBe: Megarriples (mesoforms) } \\
\text { of sandstones with erosive } \\
\text { base and basal lag } \\
\text { SBp: Megarriples (mesoforms) } \\
\text { with planar base. }\end{array}$ & $\begin{array}{ccc}0.7 m \\
0\end{array}$ & 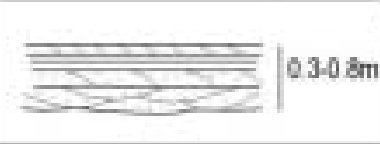 & $\begin{array}{l}\text { Nomiaty sheos } \\
\text { tat octur as } \\
\text { chantel-fil } \\
\text { Minor bars. }\end{array}$ \\
\hline E.C & & & DA: Downstream accretion & $20 \mathrm{~m}=\mathrm{sp}$ & $\infty \times \infty$ & $\begin{array}{l}\text { Convex-up 3rd } \\
\text { order internal } \\
\text { surfaces resting } \\
\text { on chanelled or } \\
\text { flat base. } \\
\end{array}$ \\
\hline A, E & $\mathrm{E}, \mathrm{A}$ & & $\begin{array}{l}\text { SGB: Sandy bedforms with } \\
\text { isolated clasts }\end{array}$ & $\begin{array}{ccc}0.7 \mathrm{~m} \\
0 \mathrm{sp}\end{array}$ & 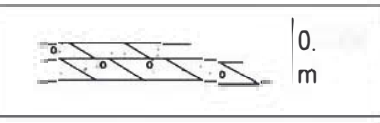 & $\begin{array}{l}\text { Flat base and } \\
\text { Superimposed } \\
\text { bars. }\end{array}$ \\
\hline \multirow[t]{2}{*}{ A } & A & A & GB: Gravel bedform & 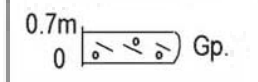 & WSECE: $10.709 \mathrm{~m}$ & $\begin{array}{l}\text { Usually erosive } \\
\text { base. }\end{array}$ \\
\hline & D.C & $C, D$ & $\begin{array}{l}\text { LS: Sandstone bodies with } \\
\text { parallel or semi-parallel } \\
\text { lamination. }\end{array}$ & 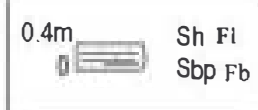 & $\begin{array}{l}=0.3-0.5 \\
\mathrm{~m}\end{array}$ & Sheet blanket \\
\hline
\end{tabular}

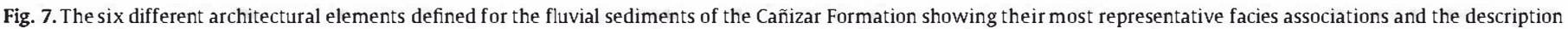

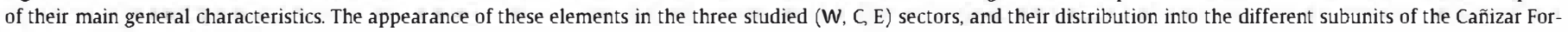
mation are shown in the left.

description of these associated facies is based upon sedimentary structures, grain characteristics and biogenic structures. Their description and interpretation are shown in Figs. 10,11 and 12. The main associated facies are: ae 1 - cross-bedded sandstone, ae 2 - wind ripplelaminated sandstone, ae 3 - horizontally bedded sandstone and ae4 - massive sandstone. The secondary facies are lesser frequent and appear associated with the four main facies and allow a precise interpretation. They appear as isolated elements, as ventifacts (vf), deformation structures (ds), or as structures which affect more extensive sedimentary surfaces such as reactivation surfaces (rs) and deflation surfaces (ds).

Three architectural elements have been differentiated as the result of the combination of the four main facies with different associated facies (Figs. 13, 14). These architectural elements are as follows:

A. Dune architectural element. This element mainly appears in sector $\mathrm{E}$, in the Benicassim section, although punctually it also appears in sectors $W$ and $C$ (Fig. 3). It is mainly constituted by facies ae1, ae2 and associated facies ad, rs, ds, ssrg, vf, dst, and gfw (Fig. 13A). It shows planar-shaped and through-shaped tongues with inversely graded sands. It sometimes forms sets reaching 3-4 $\mathrm{m}$ in thickness in sector $\mathrm{E}$, while these are thinner than $1 \mathrm{~m}$ in sectors $W$ and $C$. Where it is well-developed it is traceable for $25-30 \mathrm{~m}$ in sections parallel to the dip of the cross-bedding. Internally the sets consist of thin laminae normally lesser than $2 \mathrm{~cm}$ thick and which are frequently dominated by inversely graded grainflow cross-strata (facies gfw) and subhorizontal wind-ripple strata. Wavy-laminated strata may appear at the bases of the troughs, showing non-erosive geometry (Fig. 14a). Minor reactivation surfaces are the most common internal bounding surfaces. Interpretation. This is interpreted as having formed during the migration of the slip-faces of aeolian dunes constituting superimposed morphologies (Hunter, 1977; Chrintz and Clemensen, 1993; Rodríguez-López et al., 2010). Interfingering of grainflow strata and wavy-laminated strata perhaps represents periods of dry conditions within interdune depressions (Cain and Mountney, 2009). Grainflow soft-sediment deformation is possibly related to episodic wet conditions produced by fluvial incursions into laterally extensive interdune areas (Langford and Chan. 1989; Herries, 1992). Prevailing paleo-wind directions are considered to have been mainly from the E.NE. Cross-bedded sandstones show second- and third- order bounding surfaces (sensu Brookfield, 1977). Second-order surfaces are the most commonly represented type. These are low angle surfaces and mainly define the base of through-shaped sets. Third-order surfaces show convex-upwards shape and are located in the upper part of sets normally indicating a change in the dip of the foresets.

B. Sandsheet architectural element. This element basically appears in sector $E$ and it is poorly represented in sectors $W$ and $C$. It is composed mainly of horizontally laminated sandstones and rippled or translatent strata that have been interrupted by erosive surfaces linked to fluvial incursions (Fig. 13B). Laterally, this element may sometimes be structureless, and can be traced over some tens of meters, although its thickness never exceeds $1.2 \mathrm{~m}$ (Fig. 14c) interpretation. The sandsheet element is developed in areas of transition between fluvial to aeolian dominance (Kocurek and Nelson, 1986; Cain and Mountney, 2009). The variation of wind speed would favor the transition between plane-bed laminations and wind-ripple strata. The lateral development of these morphologies of low relief was possibly be related to the restricted sediment supply in these transitional areas (Kocurek and Nelson, 1986; Mountney, 2006).

C. Interdune architectural element. This element is mainly developed in sector $\mathrm{E}$, although some poorly developed examples are also observed in sectors $W$ and $C$. It consists of dark red, very fine-grained sandstone which is almost devoid of internal structures (Fig. 13C). Small current ripples, bioturbation, mottling and rootlets have been observed in the upper part of the Río Mayor section of sector 

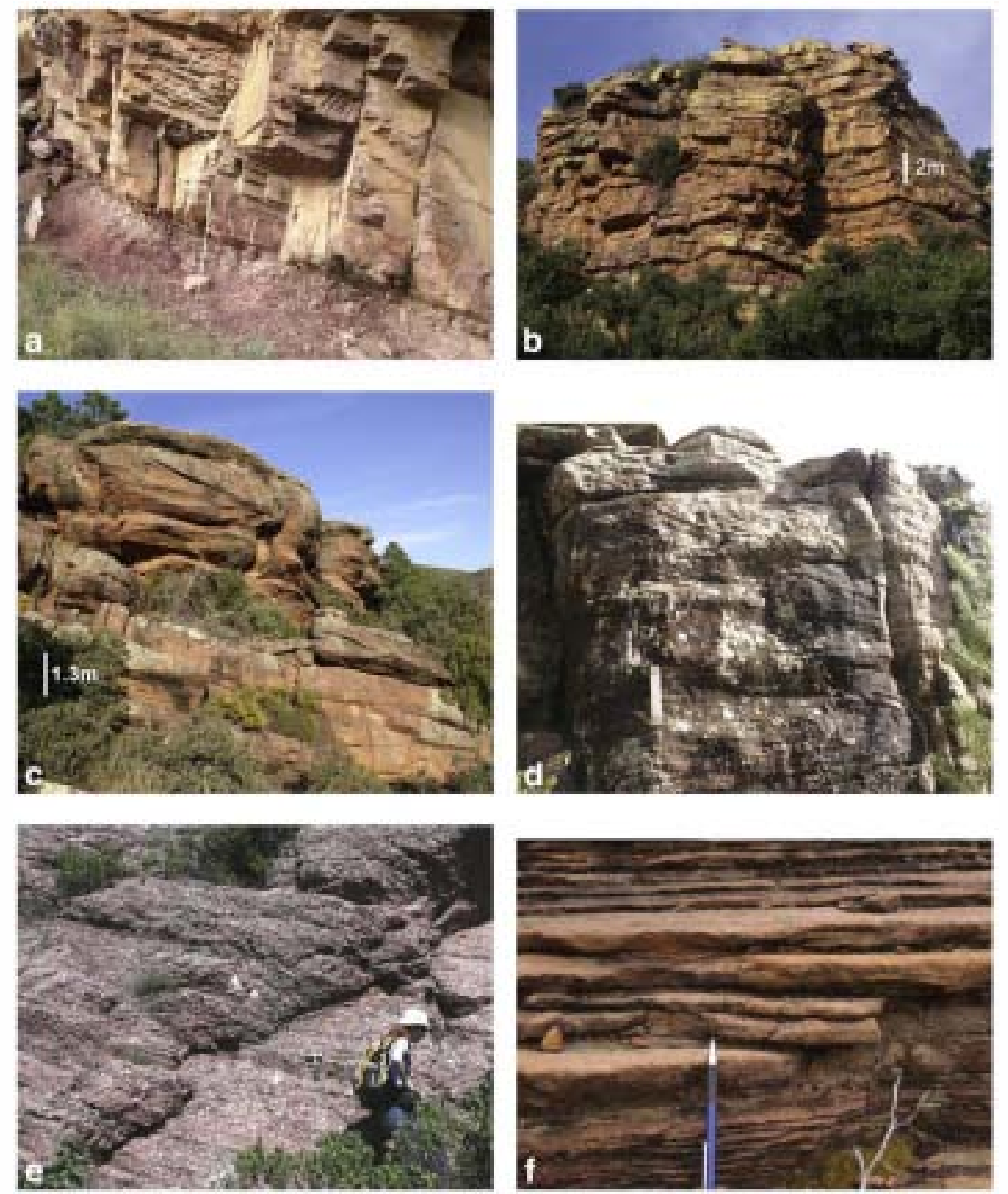

Fig. 8. View in the field of the architectural elements defined for the fluvial sediments of the Cañizar Formation. The architectural elements are: (a) $\mathrm{Channels}$ ( $\mathrm{CH}$ ), scale bar: $1 \mathrm{~m}$. (b) Megarriples with erosive base (Sbe-p). (c) Downstream accretion (DA). (d) Sandy bedforms with isolated clasts (SGB), scale bar: $0.2 \mathrm{~m}$. (e) Gravel bedform (GB) (hammer in the center-right: $26 \mathrm{~cm}$ ), (f) Sandstone bodies with parallel or semi-parallel lamination (LS) (pencil: $12 \mathrm{~cm}$ ).

W (Fig. 14b). Normally these occur as lens-shaped or sheet-like laterally extensive bodies in close relation to deposits of fluvial facies. This element may reach $0.45 \mathrm{~m}$ in thickness and is less than $12 \mathrm{~m}$ in lateral extent.

Interpretation. The interdune element probably represents interdune flats between aeolian dunes. These surfaces were close to with the capillary fringe of the water table (Mountney, 2006), where colonization by root structures and bioturbation are common (Kocurek, 1981; Loope, 1988; Hasiotis, 2002).

\subsection{General sedimentary interpretation}

The sedimentary interpretation of the Cañizar Fm. is mainly based on the architectural elements and their facies associations and thus has been done separately for the differentiated subunits and the three different areas (W, C, E). The sedimentary characteristics indicate a succession of fluvial systems as the main process of sedimentation in sectors $W$ and $C$, while both fluvial and aeolian sedimentation have been identified in the Benicassim section, sector E (Fig. 15).
The vertical evolution of the fluvial characteristics in the subunits of sectors $\mathrm{W}$ and $\mathrm{C}$ indicate the development of sandy braided fluvial systems flowing to the SE, where the Paleotethys was supposedly located (Bourquin et al., 2011). These complexes represent multilateral-multi-storey sand bodies represented by channel-fill deposits related to migrating bedforms formed of mainly linguoid and transverse bars. Overbank fines and floodplain sediments are almost absent. Similar deposits have been extensively described in ancient river systems (Cant and Walker, 1978; Miall, 1978; Crowley, 1983; Ramos et al., 1986; Bridge and Mackey, 1993; Bourquin et al., 2006; Gibling, 2006).

Both the underlying and overlying deposits (Alcotas and Eslida Fms, respectively) are formed of a variety of fluvial deposits, substantial finegrained sediments and evidence of contemporary vegetation. The change in fluvial style of the Cañizar Fm. with respect to these two formations (Arche and López-Gómez, 2005; López-Gómez et al., 2010), the absence of fine-fraction, and the braided nature of the fluvial channels with frequent abandonment and re-occupation can be explained by the absence of vegetation, especially riparian associations that 


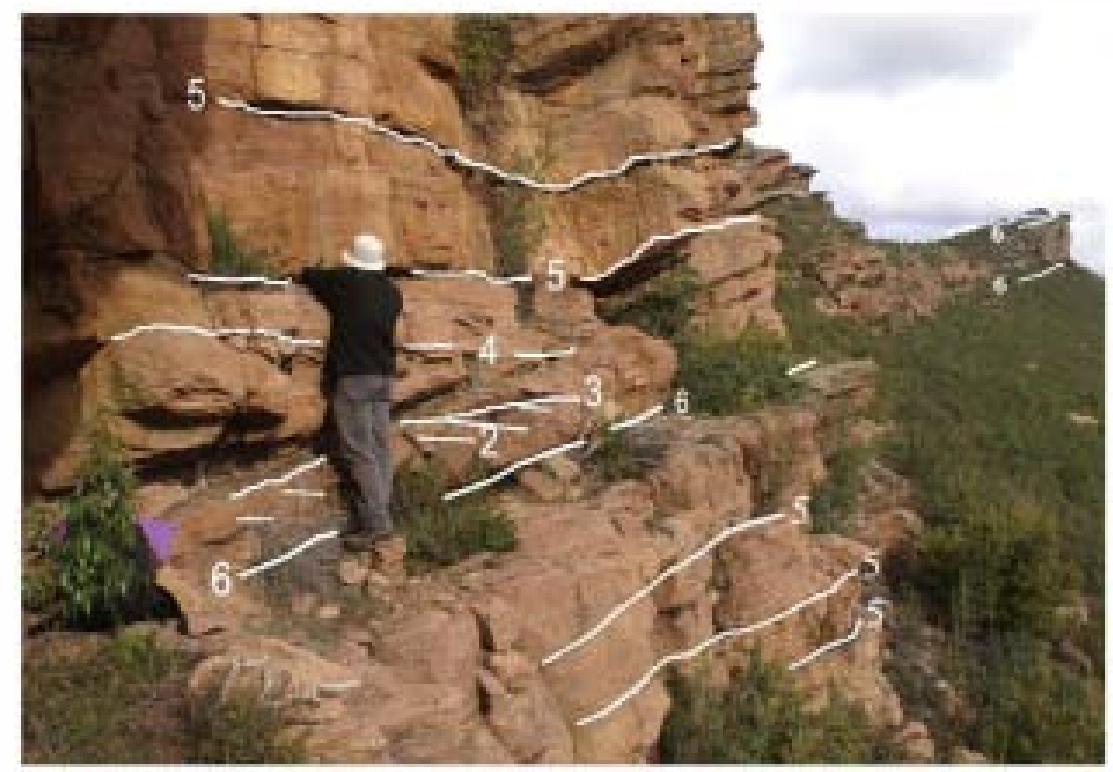

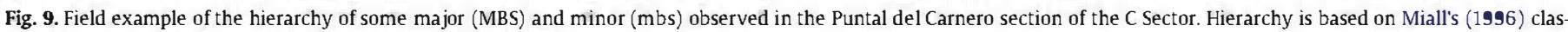
sification. Geologist's fits are located between B and C subunits.

precluded the existence of fixed banks and active chemical weathering. These conditions could resemble the pre-Devonian fluvial systems development (Love and Williams, 2000; Davies and Gibling, 2010a,b).
Aeolian erosion and reworking of the exposed sandflats during low-water stages would have been effective process of partial erosion of the upper part of the alluvial deposits in the absence of vegetation

\begin{tabular}{|c|c|c|c|}
\hline \multicolumn{4}{|c|}{ Main aeolian facies } \\
\hline Code & Facies & Description & Interpretation \\
\hline ae1 & $\begin{array}{l}\text { Cross-bedded } \\
\text { sandstones }\end{array}$ & $\begin{array}{l}\text { Salmon-pink fine to medium- } \\
\text { grained well-sorted and -rounded } \\
\text { quartz grains with planar-shaped } \\
\text { and trough-shaped tongues showing } \\
\text { inversaly graded sands. }\end{array}$ & $\begin{array}{l}\text { Migration of aeolian } \\
\text { dunes by avalanching } \\
\text { in the lee slope. }\end{array}$ \\
\hline ae2 & $\begin{array}{l}\text { Wind-ripple } \\
\text { laminated-sandstone }\end{array}$ & $\begin{array}{l}\text { Light-pink lower fine-grained } \\
\text { well-sorted quartz grains showing } \\
\text { ripples and sub-horizontal } \\
\text { lamination. }\end{array}$ & $\begin{array}{l}\text { Migration of aeolian } \\
\text { wind ripples. }\end{array}$ \\
\hline ae3 & $\begin{array}{l}\text { Horizontal laminated } \\
\text { sandstone }\end{array}$ & $\begin{array}{l}\text { Light-pink fine-grained and } \\
\text { well-sorted quartz displaying } \\
\text { horizontal lamination. Small } \\
\text { and isolated bioturbation may } \\
\text { appear. }\end{array}$ & $\begin{array}{l}\text { High-wind velocity } \\
\text { conditions with } \\
\text { possible restricted } \\
\text { available sediment. }\end{array}$ \\
\hline ae4 & $\begin{array}{l}\text { Massive aeolian } \\
\text { sandstone } \\
0.2 \mathrm{~m}\end{array}$ & $\begin{array}{l}\text { Orange to brown very } \\
\text { fine-grained sandstone devoid } \\
\text { of internal structure. Mottling } \\
\text { and rootlets may appear. }\end{array}$ & $\begin{array}{l}\text { Remnant of } \\
\text { aeolian facies }\end{array}$ \\
\hline
\end{tabular}

Fig. 10. The description and interpretation of the four main defined facies for the aeolian sediments of the Cañizar Formation. 


\section{Associated or secondary aeolian facies}

\section{ad - Avalanche deposits}

rs - Reactivation surface

ds - Deflation surface

ssrg - Steep surface composed of well-sorted grains

vf - Ventifacts

es - Erosive surface (related to fluvial scours)

dst - Deformation structure

gfw - Grainflow wedges

Fig. 11. Eight differentiated associated or secondary aeolian facies in the Cañizar Formation. They are normally associated to main facies and complete the description of the aeolian architectural elements.

cover (Mac Naughton et al., 1997; Ashworth et al., 2000), as observed in some of the described elementary sequences, especially in sector $W$.

Clear changes in the vertical evolution of the system are observed when the subunits are compared. The most important differences are related to the MBS-5 (Fig. 3). This major surface is clearly the most persistent laterally with continuity over hundreds of kilometers in the SE Iberian Ranges. MBS-5 marks a general reactivation in the system, as shown by the increase in the size of sedimentary structures and by the petrology of the sandstones, which show an increase in pebble content. More importantly, the first occurrence of paleosols, plant fragments and traces of bioturbation in the Cañizar Fm, is found just above the MBS-5. This implies a remarkable biotic and environmental change of important consequences that will be discussed later on.

Although fluvial sediments are the most characteristic in sectors $W$ and $C$, occasional aeolian architectural elements are observed in the Río Mayor, Montán, Gátova and Alfondeguilla sections. These are located mainly in the transition between the B-C and C-D subunits, and represent isolated or semi-isolated centimeter-scale aeolian bedforms intercalated in the fluvial sediments. They indicate aeolian reworking of fluvial sediments during low-waters periods and development of centimeter-scale aeolian trough sets on the top of fluvial bedforms during the seasonal dry period. Depressed water table and the lack of vegetation colonizing the sandy fluvial deposits created a temporary, easily erodible sandy sediment surface, on which accumulated aeolian deposits.

The Benicassim section is taken as representative of Sector $E$ in this paper. Except for members $B$ and $C$, differentiation of the same members described in sectors $W$ and $C$ is not easy in this sector. The lower third of the section, members $B$ and $C$, is characterized by the alternate development of fluvial and aeolian bedforms. Fluvial facies analyses indicate the presence of migrating bedforms and filling channels into a braided fluvial system (López-Gómez and Arche, 1993b). These were periodically interrupted by the development of isolated aeolian bedforms represented by the architectural element Ae-2.
The architectural element Ae-3 is the most representative of the upper part of the Benicassim section. It indicates the development of an important aeolian complex. This is as temporal interruption in its development, due to renewed fluvial sedimentation (Fig. 12b). This fluvial incursion eroded the aeolian dunes and desert pavements, and separates the aeolian sediments into two main units, each of which are about $30 \mathrm{~m}$ in thickness. Both show supersurfaces in their uppermost part that represent decreases in the aeolian sand supply (Wilson, 1973; Brookfield, 1992; Langford and Chan, 1993). This change, due to the reactivation of fluvial processes perhaps corresponds to the surface $\mathrm{E}$ represented by the transition of members $\mathrm{D}$ and $E$ in sectors $W$ and $C$, that is, MBS-5. These intercalated beds of fluvial deposits in the Benicassim section contain tetrapod footprints (Gand et al., 2010).

Sector E broadly represents an incursion from the NNE of an aeolian domain that converged with the fluvial systems coming from the NW (Fig. 15). The presence of these aeolian sand bodies was probably related to the extremely arid periods that occurred during the Olenekian in the western Peri-Tethyan areas (Bourquin et al., 2011; Soria et al., 2011) and are probably linked with the southern Catalan Range, where Marzo (1980) described similar aeolian facies for a coeval stratigraphical unit (Prades Sandstones Unit). A paleo-high located in the northern part of the study area, related to the Montalbán and Ateca faults (Figs. 1, 15), was probably controlling the incursion of the aeolian belt toward the south. A similar interaction between aeolian dunes and water-laid deposits was described by Cain and Mountney (2009) in terminal fan lobes of the Permian Organ Rock Formation, SE Utah, USA.

\section{Paleontological content and age of the Cañizar Fm.}

In the Cañizar Fm. there is no evidence of any biotic remains below member $\mathrm{E}$, all the fossil remains found are only in the upper part of this unit, just above MBS-5, the 7th order surface separating members $\mathrm{E}$ and $\mathrm{D}$. The fossil content is restricted to one pollen association (Doubinger et al., 1990), some fragments of plants, and some preserved ichnofossils: a few tetrapod traces (Gand et al., 2010) and bioturbation (Figs. 4, 16).

The pollen occurs in subunit, $\mathrm{F}$ close to Río Mayor section, sector W. It consists of an association of Alisporites toralis, Falcisporites cf. stabilis, Guthoerlisporites cancellosus, Lunatisporites sp. This association was considered as probable Aegean (lowermost Anisian) in age by Doubinger et al. (1990), Diez (2000) and Diez et al. (2010). On the other hand, fragments of plants appear in members $\mathrm{E}$ and $\mathrm{F}$ in sectors $\mathrm{W}$ and $\mathrm{C}$. These consist of brown, isolated, millimeter scale fragments without any differentiated internal structure. An incomplete swimming and trackway of Rhynchosauroides, with three digital scratches, a possible resting (cubichnia) and furrowing (pascichnia) traces have been found in the Benicassim section, sector E (Gand et al., 2010).

Isolated bioturbation occurs elsewhere in very low density. They occur in subunits $E$ and $F$ of sectors $W$ and $C$, and consist of structures representative of the Scoyenia ichnofacies, where Skolithos is practically the sole representative. Isolated decimeter-scale levels with trace roots $2-3 \mathrm{~cm}$ long appear at the base of members $\mathbf{E}$ and $\mathrm{F}$.

This data, suggests the age of the uppermost part of the Cañizar Fm is Aegean (lowermost Anisian). Other criteria which support this interpretation is the Pelsonian age (upper Anisian) of the base of the overlying Landete Fm., based on Foraminifera and Ammonites (López-Gómez et al., 1998 and Márquez et al, 1994, respectively) (Fig. 16).

The age of the lower part of the Cañizar Fm. is however not possible to define at present by means of paleontological data. However, Bourquin et al. (2007, 2011) estimated its age as middle-late Smithian (Olenekian stage, Early Triassic) (Fig. 16) by regional correlation and comparison with lateral equivalent units of areas located to the north of the study area. This is the estimated age based on 

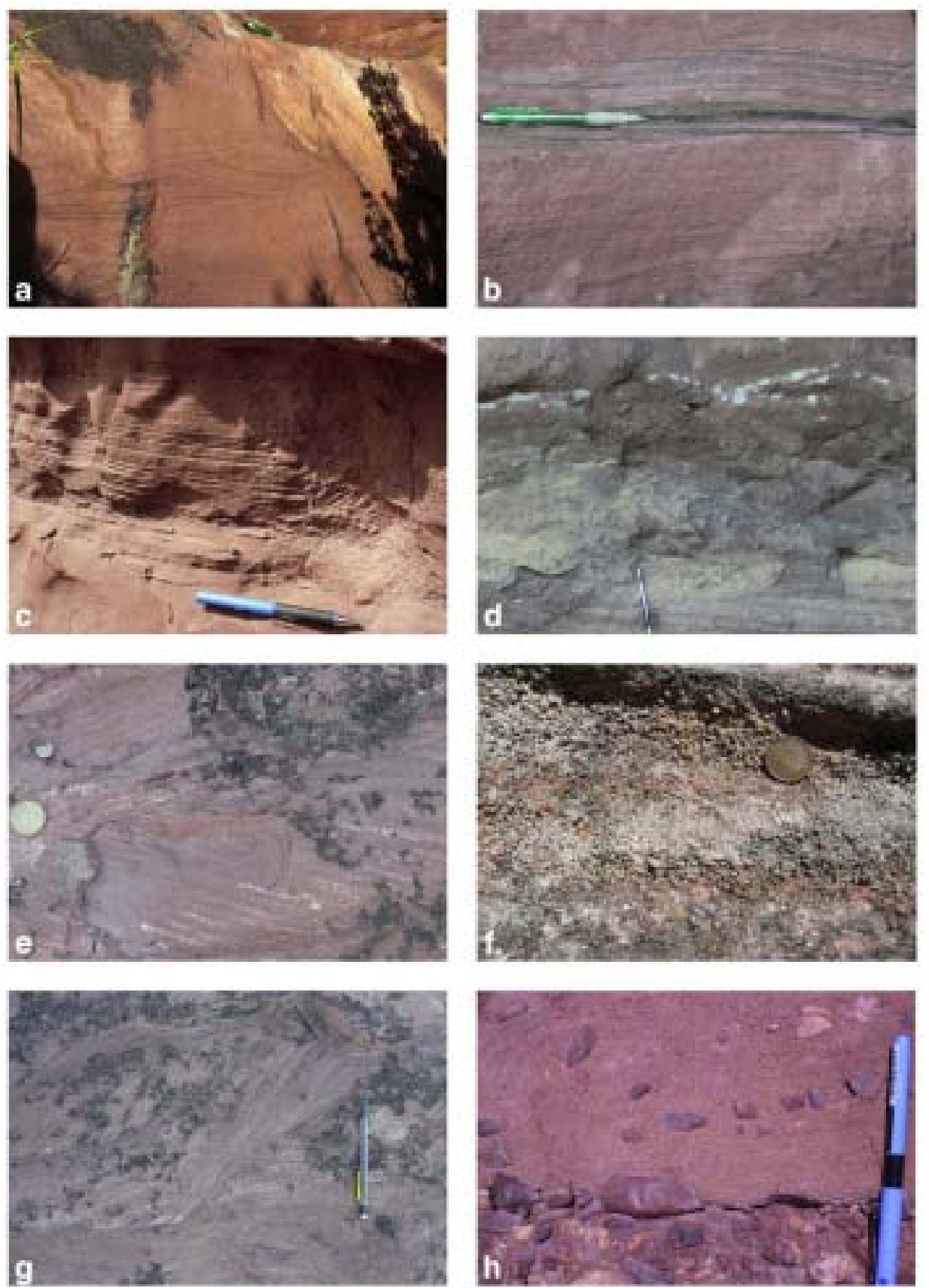

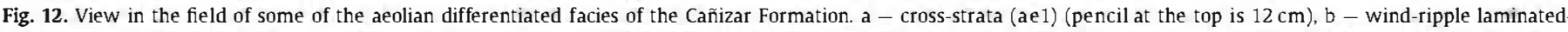

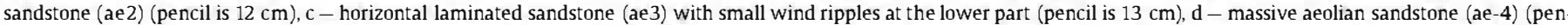

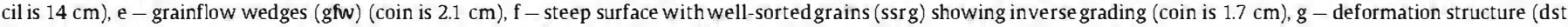
linked to avalanche process (ad) (pencil is $13 \mathrm{~cm}$ ), h - ventifacts ( $\mathrm{vf}$ ) (right of the pencil) into a deflation surface (ds). Coin is $2.5 \mathrm{~cm}$.

sedimentary criteria described here, even if we know well the objective limits of this method to date geological units. This simple calculation has been made with consideration of timespan represented by the MBS and mbs differentiated in the Cañizar Fm., as it is obvious that the sum of all the time represented by these surfaces would at least imply the minimum time that was needed in the deposition of the deposits of the Cañizar Fm. took.

This estimation has been made by considering only the surfaces of 4th to 7 th order, as those of lesser order are not very representative for the total time of deposition. As previously shown, each member has one 6th order surface at its base. A mean of eight 5th order surfaces and twenty two 4th order surfaces can be easily traced in each member (Fig. 9). If the total time of this sum based on the time they represent is considered, it would be approximately $1.650,000$ years of the whole Cañizar Fm.

To achieve a more precise figure, the time represented by the sediments (and their internal mbs) of the Cañizar Fm. which have been removed due to erosion during its deposition should also be considered, and so, this would increase the total time of sedimentation. This process of internal erosion is common in deposits of accretionary bars during the final stages of their deposition ("weaker flows" in the sense of William and Rust, 1969), as described in similar ancient fluvial systems by Bluck (1971), Blodgett and Stanley (1980) and Crowley (1983). Thorne et al. (1993) have shown also in the Brahmaputra River how bank erosion during the last three decades may reach at least $90 \mathrm{~m}$ per year. 


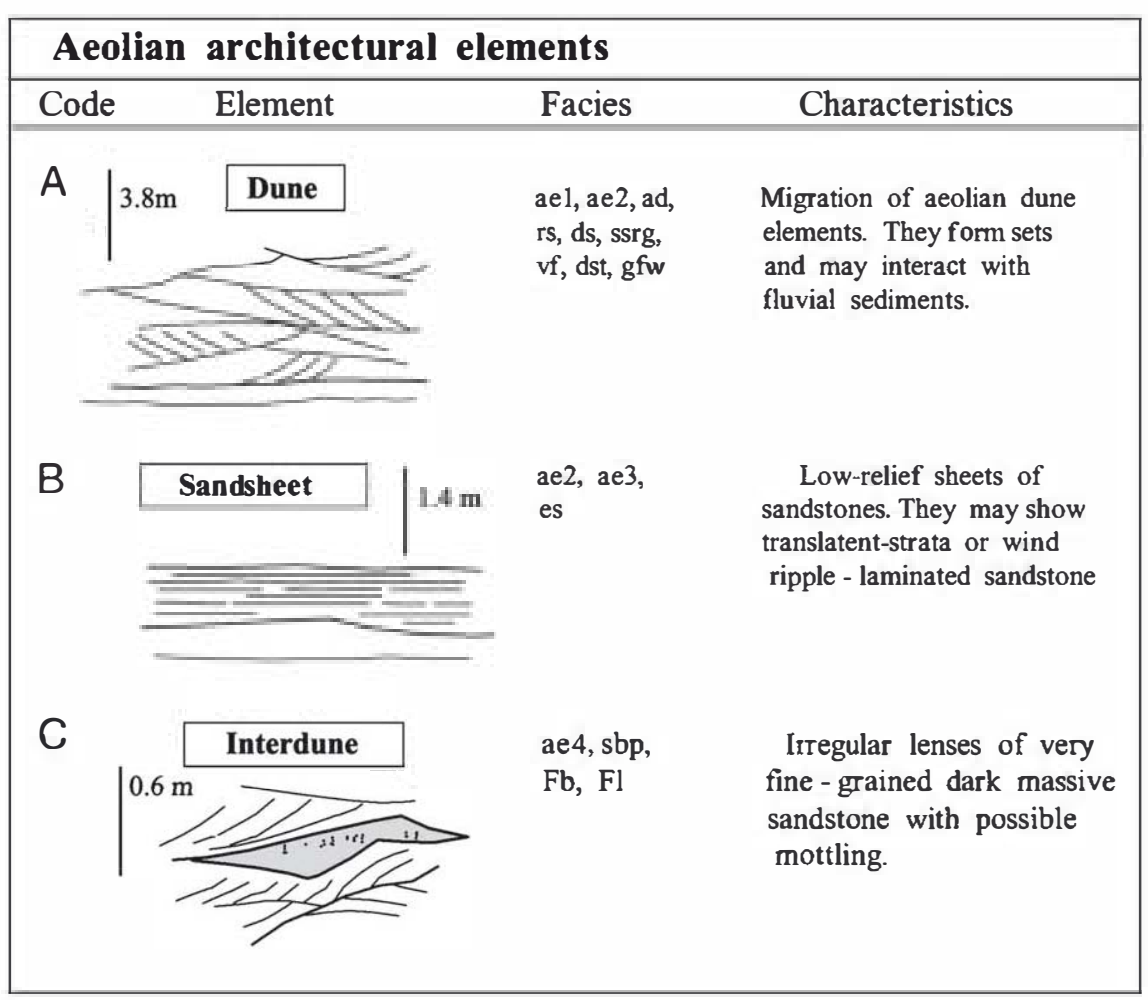

Fig. 13. The three aeolian architectural elements defined for the Cañizar Formation including their characteristics and common main and associated facies.

The addition of the results of all of these phenomena agrees generally with the above estimations of middle-late Smithian done for the age of the base of the Cañizar Fm. by Bourquin et al. (2007, 2011).

\section{Discussion}

The beginning of the Triassic of Western Europe is always represented by sediments of continental origin and there is always a marked hiatus and/or unconformity surface between these deposits and those of the underlying Permian rocks. Problems related to the precise age of these sediments, climate conditions changes, the possible causes of lack of fossil record and delay of life recovery after the Permian-Triassic biotic crises are still unresolved. The study of the Cañizar Fm. may shed light on some of these points.

\subsection{Paleogeography and climate conditions}

Studies of the paleoaltitudes of various parts of Europe during the Early Triassic (Kidder and Worsley, 2004; Péron et al., 2005; Preto et al., 2010; Roscheret al., 2011) indicate the presence of mountain belts in Central and Western Europe related to the still prominent central Variscan Belt (Bourquin et al., 2011). These paleogeographic barriers conditioned water supply in the basins of this area of the European plate that were controlled by hyper-arid to semi-arid climate in the northern and southern parts, respectively, of this mountain central belt during most of the Smithian (Ulicný, 2004; Bourquin et al., 2006, 2011).

The sedimentary characteristics of the Cañizar Fm. indicate however the occurrence of an important development of fluvial processes in the SE Iberian Basin interfingering eastwards with areas where aeolian processes were dominant during late Smithian-Spathian times. Warmer and moister conditions were probably occurred southwards of the study area, toward the high Southern Hemisphere latitudes (Woods, 2005). It appears that the SE Iberian Basin was a transition zone between those of general arid conditions to the $\mathrm{N}$ and warmer and those of moister conditions to the S. In this context, the AtecaMontalbán High, located at the northernborder of this basin, probably acted as a paleogeographical barrier separating drier conditions to the $\mathrm{N}$ from other wetter ones to the $\mathrm{S}$ (Figs. 1B, 15). This interpretation is also supported by the presence of important aeolian dune-fields in the northern part of this high, as recently described by Soria et al. (2011) and López-Gómez et al. (2011). These dune-fields may partially explain the presence of well-rounded homometric quartz windreworked grains incorporated into the fluvial systems of the studied sectors $\mathrm{W}$ and $\mathrm{C}$.

However, a detailed study of the Cañizar Fm. also shows that climate was not constant through time, but changed during the deposition of its different units. There was a stage of increased aeolian processes which is mainly related to subunits $C$ and $D$, but also in $A$ and $B$ subunits and which mostly show partial reworking of some fluvial sediments by aeolian activity in the sector $W$. This is more easily seen laterally toward sector $\mathrm{E}$, where clear aeolian dominance was established. This stage represented an arid to very arid time-interval which can be approximately located during the middle-late Smithian to early-middle Spathian. This interval unfortunately, up to now, lacks any biotic traces in the Iberian Ranges (Fig. 16).

The middle-late Smithian interval was coincident with the dry period described for the same age-interval in Central-Western Europe by Ulicný (2004), Péron et al. (2005), Durand (2006), Galfetti et al. (2007a), Cassinis et al. (2007), Preto et al. (2010), and Bourquin et al. (2011). However, it is also important to stress that in NW Europe, the early-middle Spathian was a more humid interval (Szurlies, 2007) with some paleosoils and tetrapod footprints in the rocks of the German Basin, (Detfurth and Hardegsen formations, Haubold, 1983; Fichter and Kunz, 2004), or only paleosoils in the Paris Basin ("Zone limite violette", Gall et al., 1977). These data allow speculation about some climate variations during the early-middle Spathian from Central-N to SW Europe, from approximately latitude $20^{\circ}$ to $10^{\circ}$.

Different sedimentary and biotic indicators show that this period of arid to very arid conditions suddenly changed during the sedimentation of the upper part of the Cañizar Fm., probably in the middle- 

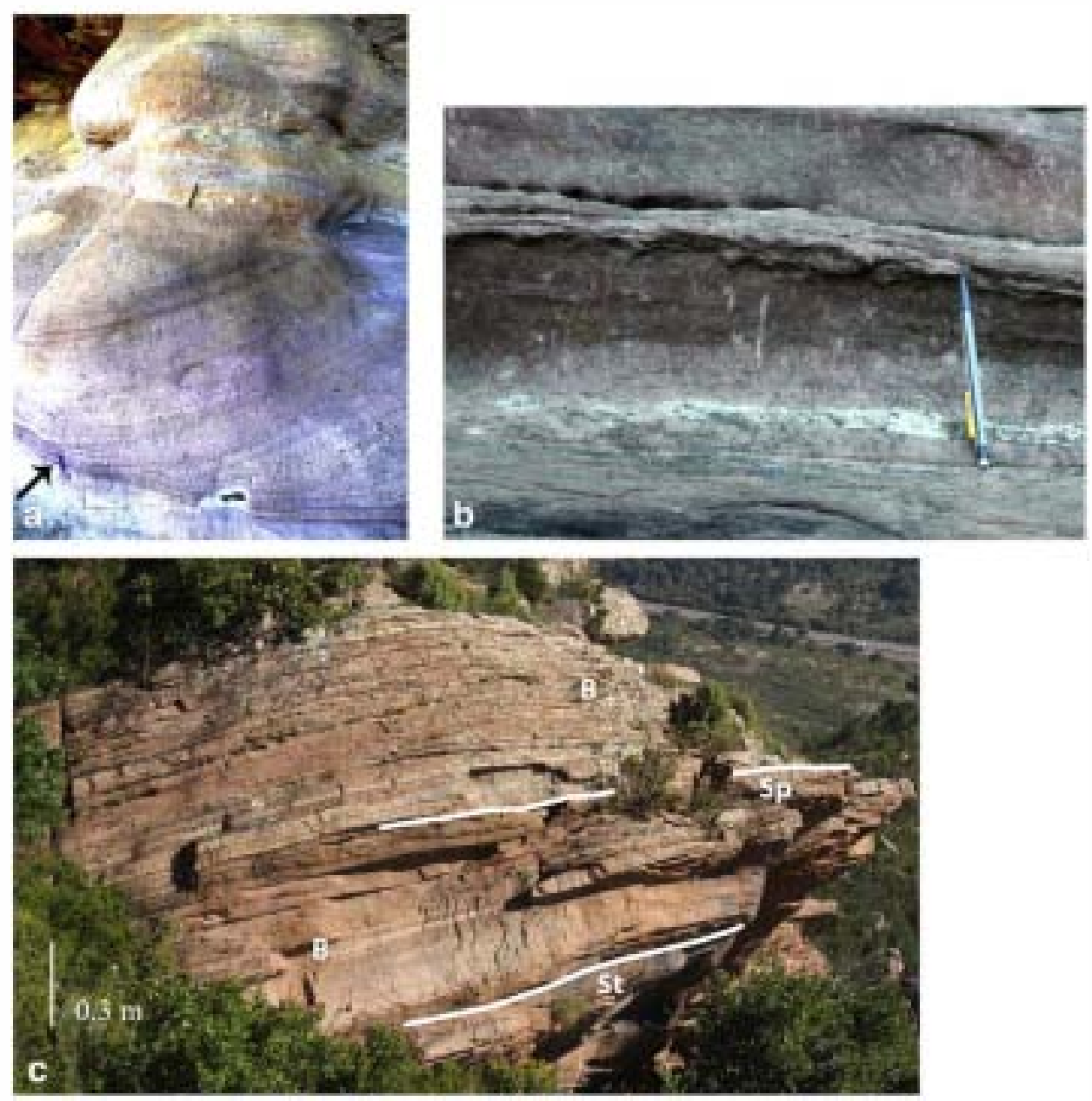

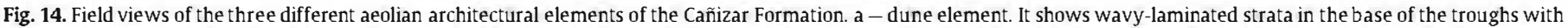

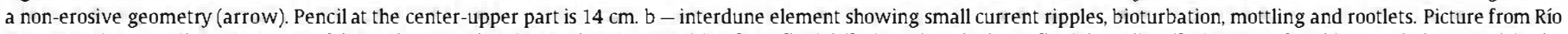

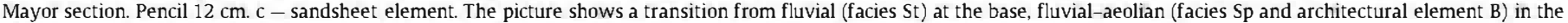
middle part, to aeolian sandsheet showing plane-bed lamination and wind-ripple strata (architectural element B) in the upper part.

late Spathian. This time-interval was related to the transition from members D to E, and so, is related to MBS-5. It was coincident with the appearance of paleosols, thin intercalated clay layers, bioturbation, tetrapod footprints and the to-date only pollen and spore association preserved in the Cañizar Fm. All of these characteristics indicate slightly more humid conditions, but also indicate the first appearance of life after the Permian-Triassic biotic crisis in this area of the Western Tethys (Fig. 16). It is important to state that life traces, such as pollen and fossil tetrapod footprints, were already described in sediments of Induan age in Central German Basin (Swiecicki et al., 1995).

After a new brief period of dry conditions indicated by the deposits of the top of subunit $\mathbf{E}$, during the Spathian-Anisian transition, new slightly humid conditions were re-established during the early Anisian, during the deposition of the top of the Cañizar Fm. and were maintained during most of the time of the Eslida Fm. sedimentation.

These arid and semi-arid climate fluctuations during the SmithianSpathian interval were possibly related to the still prevailing elevated $\mathrm{CO}_{2}$ values caused by coeval episodic volcanic activity well after the emplacement of the Siberian Traps (Royer, 2006; Payne and Krump, 2007; Brüihwiler et al., 2009). Carbon isotope excursions have been studied in detail in the last decade in different marine basins of the world and used for identification of drastic changes during the Olenekian and the transition to the Anisian (late Early Triassic-early Middle Triassic), where some large and short-lived fluctuations occurred (Galfetti et al., 2007a,b; Krystyn et al., 2007; Payne and Krump,
2007; Richoz et al., 2007; Briihwiler et al., 2009). Three important shifts in the carbon isotope excursions were observed in the late Early Triassic and were broadly located in the middle Smithian, in the Smithian-Spathian and in the Spathian-Anisian transitions (Baud et al., 1996; Payne and Krump, 2007; Sellwood and Valdes, 2007).

These inferred volcanic episodes and the general absence of a vegetated cover, as shown by the rocks of the Cañizar Fm., would have favored intense weathering of the basement rocks of the continental Early Triassic basins and increase of run-off and the influx of more terrigenous sediments to the basin (Retallack, 1999), as it is also corroborated by the ${ }^{87} \mathrm{Sr}$ and ${ }^{143} \mathrm{Nd}$ data (Martin and Macdougall, 1995; Uysal et al., 2007; Hartmann et al., 2009). These circumstances would allow active channel lateral migration. Avulsion processes due to the lack of riparian vegetation stabilizing the banks of the channels were frequent allowing multi-storey development of the sedimentation.

\subsection{Tectonics and life recovery}

The Permian-Triassic transition in Western Europe is usually represented by a hiatus and/or a clear angular unconformity (Bourquin et al., 2007, 2011). Although this tectonic activity and time without sedimentation or erosion were variable depending on the studied basin of this area, the continental sedimentary record of the Mesozoic cycle always started during the Smithian-Spathian 


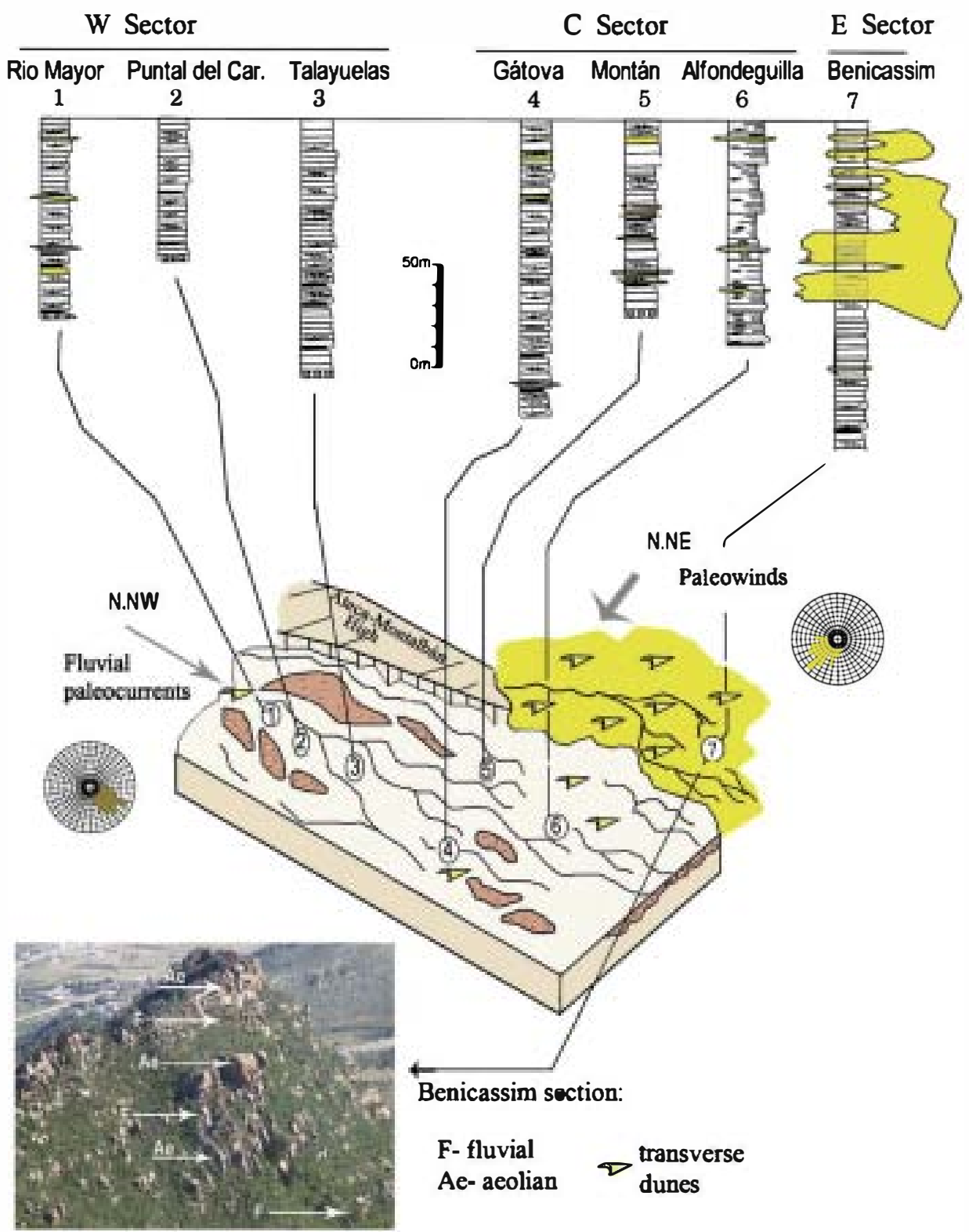

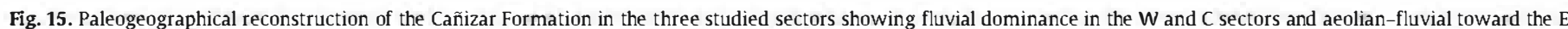

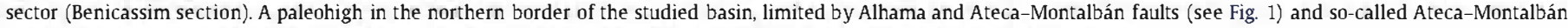
High represented an important paleogeographic barrier in the sedimentation isolating more humid areas toward the S and SW.

(Olenekian, Early Triassic) except in central German Basin, where there is a continuous sedimentary record from the Induan (Szurlies, 2007).

Late Paleozoic-Late Triassic construction and dismemberment of Pangea and the possible associated volcanism are thought to have profoundly altered atmospheric circulation over tropical regions (e.g. Tabor and Montañez, 2002; Woods, 2005; Galfetti et al., 2007a). These changes led to general and local paleogeographical modifications as climate shifts and consequent changes in weathering intensity which modified the general atmospheric $\mathrm{CO}_{2}$ balance (Martin and Macdougall, 1995; Retallack, 1999; Payne et al., 2004; Royer et al., 2004; Hartmann et al., 2009).

The sediments of the Cañizar Fm. and those of the above cited basins were deposited in rift systems resulting from reactivation of previous Permian basins (Nikishin et al., 2002). Active tectonics caused punctuated phases of reactivation during the Smithian in most of West-Central Europe basins (Twitchett, 1999). As a result, different sedimentary breaks and major boundary surfaces (MBS) appeared intercalated in the sedimentary record. This is well demonstrated in the MBS of the Cañizar Fm. (Figs. 4, 16), but also clearly recognizable in other basins, such as the Paris Basin and western part of the Germanic Basin (Aigner and Bachmann, 1992; Bourquin et al., 2006). Each of these MBS separates continental depositional cycles that show tendency of base-level rise and a possible interruption at their top, which was later reactivated by a new tectonic pulse.

The seven MBS described for the Cañizar Fm. can be traced all along the central-eastern Iberian Ranges, indicating that coeval rifting phases were affecting this broad area (López-Gómez and Arche, 1993b; Vargas et al., 2009). There is still no proof to demonstrating that these phases were related to the MBS of similar age observed in other European basins. However, the MBS-5, separating subunits $\mathrm{D}$ and $\mathrm{E}$, which is the most important one from the paleogeographical point of view in the Iberian Ranges and was recently also been observed in the Catalonian Ranges, NE Iberian Peninsula (GalánAbellán, 2011) is thought to have an intra-Spathian age, and may be related to the Hardegsen unconformity, of similar age, described in 


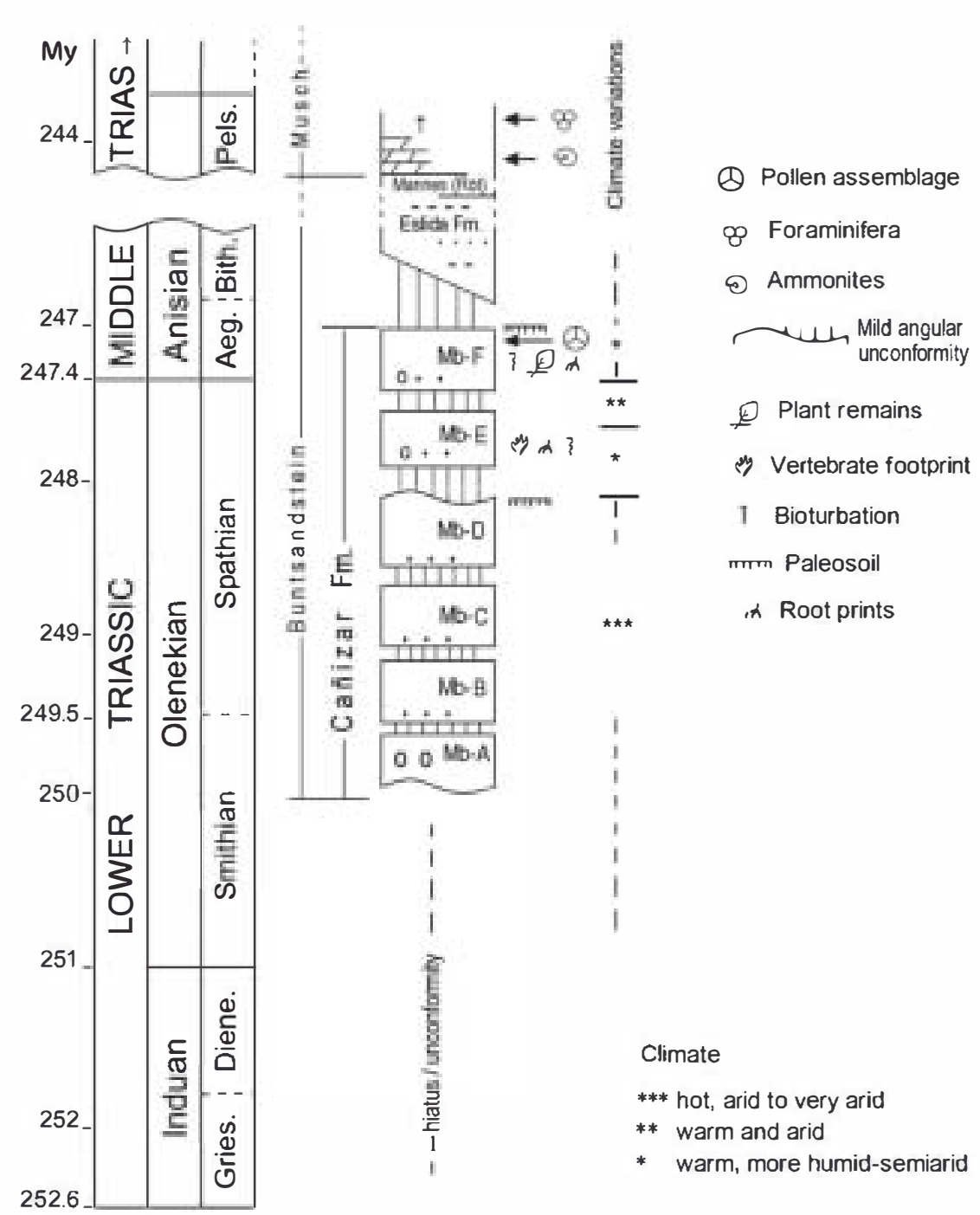

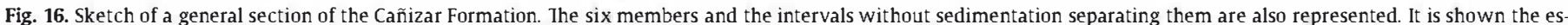

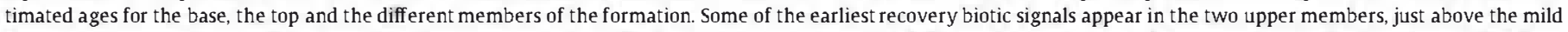

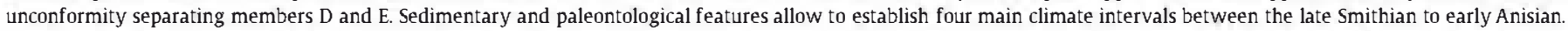

detail in the Vosges (NE France), central Germanic basin and Paris basin (Bourquin et al., 2006, 2009; Bourquin and Durand, 2007), and the Triassic Cheshire basin, UK (Mountney and Thompson, 2002). In fact, a major tectonic phase of the same age was related to an important structural reorganization in NW Europe (Geluk, 2005), which could be related to the final phase of collapse of the Variscan Belt (Röhling, 1991).

The analogies of the Cañizar Fm. with other coeval units of neighboring basins of western Tethys perhaps indicate that general uniform paleoecological conditions existed during the Early Triassic over extensive areas (Cassinis et al., 2003; Payne et al., 2004; Galfetti et al., 2007a; Cassinis et al., 2012). It would have included vast surfaces with a general depleted oxygen content, punctuated by elevated $\mathrm{CO}_{2}$ values and general acidic conditions that prevailed after the catastrophic $\mathrm{P} / \mathrm{T}$ boundary volcanic event in Siberia until middle Spathian, when new, improved paleoenvironmental conditions allowed life recovery (Twitchett, 1999).

As it is shown in the Cañizar Fm., these new paleoenvironmental conditions also allowed slow re-establishment of biotic diversity in the Iberian Basin, where first signals of life, such as tetrapod footprints, plant fragments, bioturbation and paleosols occurred just above the MBS-5, in member E, during middle-late Spathian (Fig. 16), but it is not until the early Anisian, during deposition of the Eslida Fm., about 1 My later, that diversity showed a clear increase in this area, as shown by the presence of different paleontological groups (Béthoux et al., 2009; Gand et al., 2010; Galán-Abellán, 2011). Therefore, the first signals of recovery of life in the SE Iberian Basin started just after the unconformity represented by MBS-5, a 7th order surface that we have been related to the coeval tectonic event in Western and Central Europe mirrored by the so-called Hardegsen unconformity. The absence of any biological activity traces in the Early Triassic of the Iberian Ranges does not imply that this area was an absolute biological desert, only that populations were very sparse.

Changes in paleoenvironmental and geochemical conditions could be so related to tectonic activity allowing new possibilities for the recovery of life in the middle Spathian. The creation of new geographical corridors that would favor an increase of water oxygenation and animal migration allowing their installation in areas with more suitable life conditions could be related to this activity.

Prolonged general disturbances and delay in the recovery of life in the Early Triassic in most of Pangea are probably related to a chain of processes. Simple evidence of this fact is the similar general sedimentary record observed in different and geographically separated continental basins. Volcanic pulses during the Early Triassic and its related prolonged geochemical anomalies could be a linking cause for the above mentioned lack of vegetated cover, $\mathrm{CO}_{2}$ anomalies and weathering (Payne and Krump, 2007). Carbon cycle disturbances continued through the Early Triassic during an interval of approximately 
5 My with an excursion of its isotope characterized by positive and negative shifts (Galfetti et al., 2007a,b; Richoz et al., 2007; Brühwiler et al., 2009). These types of fluctuations could have delayed 5-10 My the appearance of generalized signals of the recovery of life since the beginning of the Triassic (Erwin, 1993, 2006; Hallam and Wignall, 1997; Brayard et al., 2006).

\section{Conclusions}

The Cañizar Fm. represents the beginning of the first Mesozoic cycle of sedimentation in the Iberian Basin after the Permian-Triassic crisis and paleoenvironmental changes. It is subdivided into six members (A-F) separated by major boundary surfaces (MBS). The sedimentological and paleontological study of this unit allows a comparison of some paleoenvironmental characteristics which can be observed in neighboring basins of SW Europe during this special period of time.

Each of the MBS may represent a time-span of about $10^{4}$ $10^{5}$ years and can be traced laterally over hundreds of kilometers, indicating to a regional tectonic origin. Renewed activity along the basin boundary faults changed local and/or regional slopes, causing partial erosion of previous sediments and fluvial network changes.

The age of the uppermost part of the Cañizar Fm. is lower Anisian according to a pollen association, and the age of the base is here estimated as middle-late Smithian based on elemental sedimentary calculations of the MBS and sedimentary sequences time span and the comparison with other described coeval series of neighboring basins.

Detailed study on facies and architectural elements defined in the Cañizar Fm. allows the determination of its fluvial origin with some punctuated aeolian incursions for the western and central areas, and a mixed aeolian and fluvial origin in the eastern area of the Iberian Ranges, close to the present-day Mediterranean coast. These data allow the recognition of the Ateca-Montalbán High, at the northern border of the study area, as a topographic barrier separating the northern-eastern aeolian dominated zone from the southern mainly fluvial dominated zone. This barrier was probably not only of local significance in the Iberian Basin, but also for western Tethys area.

The sedimentary characteristics and fossil record of the upper part of the unit record different shifts in climate conditions during the sedimentation of the Cañizar Fm. The climate ranged from semiarid to arid, with at least two marked arid periods in the middle-late Smithian to middle Spathian, mainly affecting to B, C and D members, and a short one during the Spathian-Anisian transition, at the top of $\mathrm{E}$ member. They are intercalated with two more humid periods during the late Spathian and in the early Anisian, at the top of the unit, affecting $\mathrm{E}$ and $\mathrm{F}$ members. The lower middle-late Smithian to middle Spathian arid interval contrasts with a more humid interval of similar age in $\mathrm{N}$ and Central Europe.

Finally, MBS-5 is estimated to have a late Spathian age, and is represented by a slight unconformity due to a clear sedimentary and tectonic reorganization in the Iberian Basin. The beginning of the first signals of biotic recovery in the Iberian Basin and the appearance of the necessary environmental conditions for this recovery are observed just above MBS-5, about 5 My after the Permian-Triassic formation of the boundary, although it is not approximately until 1 My later, as seen in the Eslida Fm., that clear life signals appear.

The age of this first fossil record in the Iberian Basin contrasts with that of the Induan one described for the first fossil record in $\mathrm{N}$ and Central Europe. It is perhaps related to a more arid climate conditions extended until the middle Spathian in the Iberian basin.

The age, stratigraphy and general sedimentary characteristics of MBS-5 surface allow a comparison with the coeval Hardegsen unconformity defined for Central-Western Europe and so, clearly indicates tectonic activity of regional extent for this broad area. These data allow a consideration of the possible relationship of tectonic activity and related development of geographical corridors with biotic recovery in the study area.

\section{Aknowledgements}

This paper is a contribution to the Projects CGL2008-00093, CGL2011-24408 and CGL2010-09503-E of the Spanish Ministry and to Projects UCM-BSCH-GR58/08: Análisis de Cuencas (910429) and Paleoclimas (910198) of the Universidad Complutense-Comunidad Autónoma de Madrid. We thank Ausonio Ronchi, Meshach Isaac and Gert Jan Weltje for improving the manuscript with their detailed reviewing, and Graham Evans for his kind revision of the English. We thank Maribel Benito for field support.

\section{References}

Aigner, T., Bachmann, G.H., 1992. Sequence-stratigraphic framework of the German Triassic. Sedimentary Geology 80, 115-135.

Allen, J.R.L., 1963. The classification of cross-stratified units, with notes on their origin. Sedimentology 2, 93-114.

Allen, J.R.L., 1983. Studies on fluviatile sedimentation: bar, bar complexes and sandstone sheets (low-sinuosity braided streams) in the Brownstones (L. Devonian), Welsh Borders. Sedimentary Geology 33, 273-293.

Alonso-Azcárate, J., Arche, A., Barrenechea, J.F., López-Gómez, J., Luque, J., Rodas, M. 1997. Palaeogeographical significance of the clay minerals in the Permian and Triassic sediments of the SE Iberian Ranges. Palaeogeography, Palaeoclimatology, Palaeoecology 136, 309-330.

Arche, A., López-Gómez, J., 1996. Origin of the Permian-Triassic Iberian Basin, Central Spain. Tectonophysics 266, 433-464.

Arche, A., López-Gómez, J., 1999. Subsidence rates and fluvial architecture of riftrelated Permian and Triassic alluvial sediments of the southeastern Iberian Range, Eastern Spain. In: Smith, N.D., Rodgers, N. (Eds.), Fluvial Sedimentology V, Spec. Publ. Int. Ass. Sedimentology, 28, pp. 283-384.

Arche, A., Iópez-Gómez, J., 2005. Sudden changes in fluvial style across the PermianTriassic boundary in the Eastern Iberian Ranges, Spain: analysis of possible causes. Palaeogeography, Palaeoclimatology, Palaeoecology 229, 104-126.

Ashley, G.M., 1990. Classification of large-scale subaqueous bedforms: a new look at the old problem. Journal of Sedimentary Petrology 60, 160-172.

Ashworth, P.J., Best, J.L., Roden, J.E., Bristow, C.-S., Llaasen, G.J., 2000. Morphological evolution and dynamics of a large sand braided-bar, Jamuna River, Bangladesh. Sedimentology 47, 533-555.

Atudorei, V., Baud, A., 1997. Carbon isotope events during the Triassic. Albertiana 20, 45-49.

Baud, A., Atudorei, V., Sharp, 2., 1996. Iate Permian and Early Triassic evolution of the Northern Indian Margin: carbon isotope and sequence stratigraphy. Geodinamica Acta 9, 57-77.

Benton, M.J., 2003. When Life Nearly Died. The Greatest Mass Extinction of All Time. Thames \& Hudson, London. 336 pp.

Béthoux, O., De La Horra, R., Benito, M.B., Barrenechea, J.M., Galán, López-Gómez, J. 2009. A new triadotypomorphan insect from the Anisian (Middle Triassic), Buntsandstein facies, Spain. Journal of Iberian Geology 35 (2), 179-184.

Blodgett, R.H., Stanley, K.O., 1980. Stratification bedforms and discharge relations of the Platte braided system, Nebraska. Journal of Sedimentary Petrology 50, 139-148.

Bluck, B.J., 1971. Sedimentation in the meandering river Endrick. Scottish Journal of Geology 7, 93-178.

Bott jer, D.J., Clapham, M.E., Fraiser, M.L., Powers, C.M., 2008. Understanding the mechanisms for the end-Permian mass extinction and the protracted Early Triassic aftermath and recovery. GSA Today $18(9), 4-10$.

Bourquin, S., Durand, M., 2007. The Triassic of eastern France. International field work shop of the Pan-European correlation of epicontinental Triassic. Mémoires Geosciences Rennes 580 pp.

Bourquin, S., Péron, S., Durand, M., 2006. Lower Triassic sequence stratigraphy of the western part of the Germanic Basin (west of Black Forest): fluvial system evolution through time and space. Sedimentary Geology 186, 187-211.

Bourquin, S., Durand, M., Díez, J.B., Broutin, J., Fluteau, F., 2007. The Permian-Triassic boundary and Lower Triassic sedimentation in the Western European Basins: an overview. Journal of Iberian Geology 33, 221-236.

Bourquin, S., Guillocheau, F., Péron, S., 2009. Braided river within an arid alluvial plain (example from the Early Triassic, western German Basin): criteria of recognition and expression of stratigraphic cycles. Sedimentology 56, 2235-2264

Bourquin, S., Bercovici, A., Iópez-Gómez, J., Díez, J.B., Broutin, J., Ronchi, A., Durand, M. Arche, A., Linol, B., Amour, F., 2011. The Permian-Triassic transition and the onset of Mesozoic sedimentation at the northwestern peri-Tethyan domain scale: palaeogeographic maps and geodynamic implications. Palaeogeography, Palaeoclimatology, Palaeoecology 299, 265-280.

Bown, T.M., Kraus, M., 1987. Integration of channeland floodplain suits, I. Development of sequence and lateral relations of alluvial paleosols. Journal of Sedimentary Petrology 57, 587-601.

Brayard, A., Bucher, H., Escarguel, G., Fluteau, F., Bourquin, S., Galfetti, T., 2006. The Early Triassic ammonoid recovery: paleoclimatic significance of diversity gradients. Palaeogeography, Palaeoclimatology, Palaeoecology 239, 374-395. 
Bridge, J.S., 1993. The interaction between channel geometry, water flow, sediment transport and deposition in braided rivers. In: Best,J.L., Bristow, C.S. (Eds.), Braided Rivers: Geological Society Special Publication, 75, pp. 13-71.

Bridge, J.S., Mackey, S.D., 1993. A revised alluvial stratigraphy model. In: Marzo, M., Puigdefábregas, C. (Eds.), Alluvial Sedimentation: IAS. Special Publication, 17 pp. 319-336.

Bristow, C.S., Best, J.L., 1993. Braided rivers: perspectives and problems. In: Best, J.L., Bristow, C.S. (Eds.), Braided Rivers: Geological Society Iondon Special Publication, 75, pp. 1-11.

Brookfield, M.E., 1977. The origin of bounding surfaces in ancient eolian sandstones Sedimentology 24, 302-332.

Brookfield, M.E., 1992. Eolian systems. In: Walker, R.G., James, N.P. (Eds.), Facies Models. Response to Sea Level Change: Geological Association of Canada pp. 143-156.

Brühwiler, T., Goudemand, N., Galfetti, T., Bucher, H., Baud, A., Ware, D., Hermann, E., Hochuli, P.A., Martín, R., 2009. The Lower Triassic sedimentary and carbon isotope records from Tulong (South Tibet) and their significance for Tethyan palaeoceanography. Sedimentary Geology 222, 314-332.

Cain, S.A., Mountney, N.P., 2009. Spatial and temporal evolution of a terminal fluvial fan system: the Permian Organ Rock Formation, South-east UTA, USA. Sedimentology $56,1774-1800$.

Cant, D.J., Walker, R.G., 1978. Fluvial processes and facies sequences in the sandy braid ed South Saskatchewan River, Canada. Sedimentology 25, 625-648.

Capote, R., González-Lodeiro, F., 1983. La estructura herciniana de los afloramientos paleozoicos de la Cordillera Ibérica. In: Comba, J. (Ed.), Libro Jubilar J. M. Ríos 1 pp. 513-519

Cassinis, G., Durand, M., Ronchi, A., 2003. Permian-Triassic continental sequences of northwest Sardinia and south Provence: stratigraphic correlations and paleogeographic implications. In: Decandia, F.A., Cassinis, G., Spina, A. (Eds.), Iate Palaeozoic to Early Mesozoic Events of Mediterranean Europe, and Additional Regional Reports. Siena 2011: Bolletino della Società Geologica Italiana, 2, pp. 119-129.

Cassinis, G., Durand, M., Ronchi, A., 2007. Remarks on the Permian and Permian-Triassic boundary in central and eastern lambardy (Southern Alps, Italy). Journal of Iberian Geology 33 (2), 133-142.

Cassinis, G., Perotti, C., Ronchi, A., 2012. Permian continental basins in the Southern Alps (Italy) and peri-mediterranean correlations. Intemational Joumal of Earth Sciences (Geol Rundsch.) 101 (1), 129-157.

Chen, Z.Q., Tong, J., Kaiho, K., Kawahata, H., 2007. Onset of biotic and environmental recovery from the end-Permian mass extinction within 1-2 million years: a case study of the Lower Triassic of the Meishan section, South China. Palaeogeography, Palaeoclimatology, Palaeoecology 352, 176-187.

Chrintz, T., Clemensen, L.B., 1993. Draa reconstruction, the Permian Yellow Sands, northeast England. In: Pye, K., Iancaster, N. (Eds.), Aeolian Sediments. Ancient and Modern: IAS. Special Publication, 16, pp. 151-162.

Crowley, K.D., 1983. Iarge-scale bed configurations (macroforms), Plate River Basin, Colorado and Nebraska: primary structures and formative processes. Bulletin Geological Society of America 94, 117-133.

Davies, N.S., Gibling, M.R., 2010a. Paleozoic vegetation and the Silurian-Devonian rise of fluvial lateral accretion sets. Geology 38, 51-54

Davies, N.S., Gibling, M.R., 2010b. Cambrian to Devonian evolution of alluvial systems: the sedimentological impact of the earliest land plants. Earth-Science Reviews 98 $171-200$

De laHorra, R, Iópez-Gómez,J., Arche, A., 2005. Caracterización de la unidad Conglomerados de Valdemeca en la transición Pérmico-Triásico de la Condillera Ibérica centro-oriental Geo-Temas 8, 141-145.

De Vicente, G., Vegas, R., Muñoz-Martín, A., Van Wees, J.D., Casa-Sainz, A., Sopeña, A Sánchez-Moya, Y., Arche, A., López-Gómez, J., Olaiz, A., Fernández-Iozano, J. 2009. Oblique strain partitioning and transpression on an inverted rift: the Castillian Branch of the Iberian Chain. Tectonophysics 470, 224-242.

DeCelles, P.G., Gray, M.B., Ridway, K.D., Cole, RB., Pivnik, D.A., Pequera, N., Srivastana, $P ., 1991$. Controls on synorogenic alluvial-fan architecture, Beartooth Conglomer ate (Paleocene), Wyoming and Montana. Sedimentology 38, 567-590.

Díez, J.B., 2000. Geología y Paleobotánica de la Facies Buntsandstein en la Rama Aragonesa de la Cordillera Ibérica. Implicaciones bioestratigráficas en el Perithetys Occidental. Ph.D Thesis. Universidad de Zaragoza (Spain) and Univ. Paris 6, (France) Unpublished.

Diez, J.B., Broutin, J., Grauvogel-Stamm, L., Bourquin, S., Bercovici, A., Ferrer, J., 2010. Anisian Floras from the NE of Iberian Penninsula and Baléaric Island: a synthesis Review of Palaeobotany and Palynology 162, 522-542.

Doubinger, J., López-Gómez,J., Arche, A., 1990. Pollen and spores from the Permian and Triassic sediments of the southeastern Iberian Ranges, Cueva de Hierro (Cuenca) to Chelva-Manzanera (Valencia-Teruel) region, Spain. Review of Palaeobotany and Palynology 66, 25-45.

Durand, M., 2006. The problem of the transition from the Permian to the Triassic series in southeastern France: comparison with other Perithethyan regions. In: Lucas, S.G., Cassinis, G., Schneider, J.W. (Eds.), Non-Marine Permian Biostratigraphy and Biochronology: Geological Society Special Publication, 265, pp. 281-295.

Erwin, D.H., 1993. The Great Paleozoic Crisis: Life and Death in the Permian. Columbia University Press, New York 327 pp.

Erwin, D.H., 2006. Extinction. How Life on Earth Nearly Ended 250 Million Years Ago Princeton University Press, Princeton, Oxford. $296 \mathrm{pp}$

Fichter, J., Kunz, R, 2004. New genus and species of chirotheroid tracks in the DetfurthFormation (Middle Bunter, Lower Triassic of Central Germany) Germany. Ichnos $11,183-193$

Filomena, C.M., Stollhofen, H., 2011. Ultrasonic logging across unconformities outcrop and core logger sonic patterns of the Early Triassic Middle
Buntsandstein Hardegsen unconformity, southern Germany. Sedimentary Geology 236, 185-196.

Galán-Abellán, A.B., 2011. Sedimentary, mineralogical and geochemical variations in the Buntsandstein facies, Iower-Middle Triassic, of the Iberian Ranges and Catalan Coastal Ranges: Implications in the recovery of the Permian-Triassic crisis. Ph.D Thesis. Universidad Complutense, Madrid. 383p. Unpublished.

Galfetti, T., Bucher, H., Brayard, A., Hochuli, P.A., Weissert, H., Guodun, K., Atudorei, V., Guex, J., 2007a. Late Early Triassic climate change: insights from carbonate carbon isotopes, sedimentary evolution and ammonoid paleobiogeography. Palaeogeography, Palaeoclimatology, Palaeoecology 243, 394-411.

Galfetti, T., Hochuli, P., Brayard, A., Bucher, H., Weissert, H., Os Vigran, J., 2007b. Smithian-Spathian boundary event: evidence for global climatic change in the wake of the end-Permian biotic crisis. Geology 35 (4), 291-294.

Gall, J.C., Durand, M., Müller, E., 1977. Le Trias de part et d'autre du Rhin: corrélations entre les marges et le centre du Bassin germanique. Bulletin Bureau Recherches Géologiques Minières, IV (3), pp. 193-204.

Gand, G., De la Horra, R., Galán-Abellán, B., López-Gómez, J., Barrenechea, J., Arche, A., Benito, M.L, 2010. New ichnites from the Middle Triassic of the Iberian Ranges (Spain): paleoenvironmental and palaeogeographical implications. Historical Biology 22 (1-3), 40-56.

Geluk, M.C., 2005. Stratigraphy and tectonics on Permo-Triassic basins in the Netherlands and surrounding areas. Ph.D Thesis. Univ. Utrecht, Netherlands. Unpublished.

Geluk, M.C., Röhling, H.G., 1997. High-resolution séquense stratigraphy of the Lower Triassic Buntsandstein: a new tool for basin análisis. In: Bachmann, G.H., Lerche, L (Eds.), Epicontinental Triassic: Zentralblatt Geologie Paläontologie, 1 (7-8), pp. $727-745$

Gibling, M.R., 2006. Width and thickness of fluvial channel bodies and valley fills in the geological record: a literature compilation and classification. Journal of Sedimentary Research 76, 731-770

Gibling, M.R., Rust, B.R., 1990. Ribbon sandstones in the Pennsylvanian Waddens Cove Formation, Sydney Basin, Atlantic Canada: the influence of siliceous duricrusts in channel-body geometry. Sedimentology $37,45-65$.

Hallam, A., 1991. Why was there a delayed radiation after the End-Palaeozoic extinc tions? Historical Biology 5, 257-262.

Hallam, A., Wignall, P.B., 1997. Mass Extinctions and Their Aftermath. Oxford University Press, Oxford. 320 pp.

Hartmann, J., Jansen, Dürr, H.H., Kempe, S., Köhler, P., 2009. Global $\mathrm{CO}_{2}$-consumption by chemical weathering: what is the contribution of highly active weathering re gions? Global and Planetary Change 69, 185-192.

Hasiotis, S.T., 2002. Continental trace fossils. SEPM. Short Course Notes, 51.132 pp.

Haubold, H., 1983. Archosaur evidence in the Buntsandstein (Lower Triassic). Acta Palaeontologica Polonica 28, 123-132.

Hermann, E., Hochuli, P.A., Bucher, H., Brühwiler, T., Hautmann, M., Ware, D., Roohi, G. 2011. Terrestrial ecosystems on North Gondwana following the end-Permian mass extinction. Gondwana Research 20, 630-637.

Herries, R.D., 1992. Sedimentology of continental erg margin interactions. Ph.D Thesis University of Aberdeen. 205 pp. Unpublished.

Hunter, R.E., 1977. Basic types of stratification in small eolian dunes. Sedimentology 24, 361-387.

Kidder, D.L., Worsley, T.R., 2004. Causes and consequences of extreme Permo-Triassic warming to globally equable climate and relation to the Permo-Triassic extinction and recovery. Palaeogeography, Palaeoclimatology, Palaeoecology 203, 207-237.

Kocurek, G., 1981. Significance of interdune deposits and bounding surfaces in eolian dune sands. Sedimentology 28, 753-780.

Kocurek, G., Nelson, J., 1986. Conditions favorable for the formation of warm-climate aeolian sand sheets. Sedimentology 33, 795-816.

Krull, E.S., Retallack, G., 2000. $\delta^{13} \mathrm{C}$ profiles from paleosols across the Permian-Triassic boundary: evidence for methane release. GSA Bulletin 112, 1459-1472.

Krystyn, L., Richoz, S., Bhargava, O.N., 2007. The Induan-Olenekian Boundary (OIB) in Mud - an update of the candidate GSSP section M04. Albertiana 36, 33-45.

langford, R.P., Chan, M.A., 1989. Fluvial-aeolian interactions: Part 11, ancient systems Sedimentology 36, 1037-1051

Iangford, R.P., Chan, M.A., 1993. Downwind changes within and ancient dune sea, Permian Cedar Mesa Sandstone, southeast Utah. In: Pye, K., Lancaster, N. (Eds.), Aeolian Sediments. Ancient and Modern: IAS Special Publication, 16, pp. 109-126.

Ioope, D.B., 1988. Rhizoliths and ancient aeolianites. Sedimentary Geology 56, 301-314.

Iópez-Gómez, J., Arche, A., 1993a. Sequence stratigraphy analysis and paleogeographic interpretation of the Buntsandstein and Muschelkalk facies (Permo-Triassic) in the SE Iberian Ranges, eastern Spain. Palaeogeography, Palaeoclimatology, Palaeoecology 103, 347-361.

Iópez-Gómez, J., Arche, A., 1993b. Architecture of the Cañizar fluvial sheet sandstones In: Marzo, M., Puigdefábregas, C. (Eds.), Alluvial Sedimentation: IAS Special Publication, 17 , pp.317-381.

Iópez-Gómez, J., Mas, R., Arche, A., 1993. The evolution of the Middle Triassic (Muschelkalk) carbonate ramp in the SE Iberian Ranges, eastern Spain: sequence stratigraphy, dolomitization processes and dynamic controls. Sedimentary Geology $87,165-193$.

Iópez-Gómez, J., Arche, A., Calvet, F., Goy, A., 1998. Epicontinental marine carbonate sediments of the Middle and Upper Triassic in the westernmost part of the Tethys sea, Iberian Peninsula. Zentralblatt fur Geologie und Palaeontologie 9-10, 1033-1084

Iópez-Gómez, J., Arche, A., Pérez-López, A., 2002. Permian and Triassic. In: Gibbons, W., Moreno, T. (Eds.), The Geology of Spain: Geololical Society of London Special Publication, pp. 185-212.

López-Gómez, J., Arche, A., Marzo, M., Duran, M., 2005. Stratigraphical and palaeogeographical significance of the continental sedimentary transition across the 
Permian-Triassic boundary in Iberia. Palaeogeography, Palaeoclimatology, Palaeoecology 229, 3-23.

Iópez-Gómez, J., Arche, A., Vargas, H., Marzo, M., 2010. Fluvial architecture as a response to two-layer lithospheric subsidence during the Permian and Triassic in the Iberian Basin, eastern Spain. Sedimentary Geology 223, 320-333.

López-Gómez, J., Arche, A., De la Horra, R., Galán-Abellán, G., Barrenechea, J.F., 2011. Permian-Triassic continental rocks of the SE Iberian Ranges: architecture, tectonics and geochemical characteristics in the context of a rift basin. In: Arenas, C., Pomar, L., Colombo, F. (Eds.), Post-Meeting Field Trips Guidebooks, 28th IAS Meeting, Zaragoza: Sociedad Geológica de España, Geo-Guías, 8, pp. 11-43.

Iove, S.E., Williams, B.J., 2000. Sedimentology, cyclicity and floodplain architecture in the Lower Old Red Sandstone of SW Wales. Geological Society of London Special Publication 180, 371-388.

Mac Naughton, R.B., Dalrymple, R.W., Narbonne, G.M., 1997. Early Cambrian braiddelta deposits, Mc Kenzie Mountains, NW Canada. Sedimentology 44, 587-600.

Márquez, L., López-Gómez, J., Trifonova, E., 1994. Datación (foraminíferos) y ambiente sedimentarios de la Formación Dolomías de landete, Ansíense, Facies Muschelkalk, provincia de Cuenca. Boletín de la Real Sociedad Española de Historia Natural 89 (1-4), 99-107.

Martín, E.E., Macdougall, J.D., 1995. Sr and Nd Isotopes at the Permian/[riassic boundary: a record of climate change. Chemical Geology 125, 73-99.

Marzo, M., 1980. El Buntsandstein de los Catalánides: Estratigrafía y procesos de sedimentación. Ph.D Thesis. Barcelona University. Unpublished.

Marzo, M., 1986. Secuencias fluvio-eólicas en el Buntsandstein del Macizo de Garraf (Provincia de Barcelona). Cuadernos de Geología Ibérica 10, 207-233.

Miall, A.D., 1978. Lithof acies types and vertical profile models in braided river deposits: a summary. In: Miall, A.D. (Ed.), Fluvial Sedimentology: Canadian Society of Petroleum Geology Memoir, 5, pp. 590-604.

Miall, A.D., 1992. Alluvial deposits. In: Walker, R.G., James, N.P. (Eds.), Facies Models: Response to Sea Level Change. Geological Association of Canada, St. John's, Newfounland, pp. 119-142.

Miall, A.D., 1995. Description and interpretation of fluvial deposits: a critical perspective: discussion. Sedimentology 42, 379-384

Miall, A.D., 1996. The Geology of Fluvial Deposits. Sedimentary Facies, Basin Analysis and Petroleum Geology. Springer-Verlag, Berlin. $582 \mathrm{pp}$

Mountney, N.P., 2006. Eolian facies models. In: Posamentier, H.W., Walker, R.G. (Eds.), Facies Models Revisited: SEPM Special Publication, 84, pp. 19-83.

Mountney, N.P., Thompson, D.B., 2002. Stratigraphic evolution and preservation of aeolian dune and dam/wet interdune strata: an example from the Triassic Helsby Sandstone Formation, Cheshire Basin, UK. Sedimentology 49, 805-834.

Nikishin, A.M., Ziegler, P.A., Abbott, D., Brunet, M.-F., Cloetingh, S., 2002. Permo-Triassic intraplate magmatism and rifting in Eurasia: implications for mantle plumes and mantle dynamics. Tectonophysics $351,3-39$.

Payne, J.L., Krump, L.R., 2007. Evidence for recurrent Early Triassic massive volcanism from quantitative interpretation of carbon isotope fluctuations. Earth and Planetary Science Letters $256,264-277$

Payne, J.L., Lehrmann, D.J., Wei, J., Orchard, M.J., Scharg, D.P., Knoll, A.H., 2004. Large perturbations of the carbon cycle during recovery from the end-Permian extinction. Science 305, 506-509.

Péron, S., Bourquin, S., Fluteau, F., Guillocheau, F. 2005. Paleoenvironment reconstruction and climate simulations of the Early Triassic: impact of the water and sediment supply on the preservation of fluvial system. Geodinamica Acta 18 (6), 431-446.

Preto, N., Kustatscher, E., Wignall, P.B., 2010. Triassic climates - state of the art and perspectives. Palaeogeography, Palaeoclimatology, Palaeoecology 290, 1-10.

Pruss, S.B., Bottjer, D.J., 2005. The reorganization of reefs communities following the end-Permian mass extinction. Comptes Rendus Palevol4, 553-568.

Pruss, S., Corsetti, F., Bottjer, D.J., 2005. The unusual sedimentary rock record of the Early Triassic: a case study from the southwestern United States. Palaeogeography, Palaeoclimatology, Palaeoecology 222, 33-52.

Ramos, A., 1979. Estratigrafía y paleogeografía del Pérmico y Triásico al oeste de Molina de Aragón (provincia de Guadalajara). Seminarios de Estratigrafía, Serie Monografías $6,1-313$.

Ramos, A., Sopeña, A., 1993. Gravel bars in low-sinuosity streams (Permian and Triassic, Central Spain). In: Collinson, J.D., Lewin, J. (Eds.), Modern and Ancient Fluvial Systems: IAS Special Publication, 6, pp. 301-312.

Ramos, A., Sopeña, A., Pérez-Arlucea, M., 1986. Evolution of the Buntsandstein fluvial sedimentation in the North-West Iberian Ranges, Central Spain. Journal of Sedimentary Petrology 56, 862-875

Retallack, G.J., 1999. Postapocalyptic greenhouse paleoclimate revealed by earliest Triassic paleosols in the Sydney Basin, Australia. GSA Bulletin 111, 55-70.
Rice, S.P., Church, M., Woolridge, C.L, 2009. Morphology and evolution of bars in a wandering gravel-bed river; lower Fraser river, British Columbia, Canada. Sedimentology 56, 709-736

Richoz, S., Krystyn, L., Horacek, M., Spötl, C., 2007. Carbon isotope record of the InduanOlenekian candidate GSSP Mud and comparison with other sections. Albertiana 35 , $35-40$.

Rodríguez-López, J.P., Meléndez, N., de Boer, P.L., Soria, A.R., 2010. The action of wind and water in a mid-Cretaceous subtropical erg-margin system close to the Variscan Iberian Massif, Spain. Sedimentology 57 (6), 1315-1356.

Röhling, H.G., 1991. A lithostratigraphic subdivision of the Lower Triassic in the Northwest German Lowlands and the German sector of the North Sea, based on gammaray and sonic logs. Geologisches Jahrbuch A 119, 3-24.

Roscher, M., Stordal, F., Svensen, H., 2011. The effect of global warming and global cooling on the distribution of the latest Permian climate zones. Palaeogeography, Palaeoclimatology, Palaeoecology 309 (3-4), 186-200.

Royer, D.L., 2006. $\mathrm{CO}_{2}$-forced climate thresholds during the Phanerozoic. Geochimica et Cosmochimica Acta 70, 5665-5675.

Royer, D.L., Berner, R.A., Montañés, LP., Tabor, N.J., Beerling, D.J., 2004. $\mathrm{CO}_{2}$ as primary driver of Phanerozoic climate. GSA today 14 (3), 4-10.

Sellwood, B.W., Valdes, P.J., 2007. Mesozoic climates. In: Haywood, W.M., Gregory, A.M., Schmidt, D.N. (Eds.), Deep-Time Perspectives on Climate Change: Marrying the Signal from Computer Models and Biological Proxies: The Micropalaeontological Society Special Publication. The Geological Society of London, pp. 201-224

Sheldon, N.D., Retallack, G.J., 2002. Iow oxygen levels in earliest Triassic soils. Geology $30(10), 919-922$

Smith, J.P., Clough, S.R., N.D., Cross, T.A., Duffic, S.R., 1989. Anatomy of an avulsion. Sedimentology $36,1-23$.

Soria, A.R., Liesa, C., Rodriguez-López, J.P., Meléndez, N., De Boer, P., Meléndez, A., 2011. An Early Triassic evolving erg system (Iberian Chain, NE Spain): paleoclimate im plications. Terra Nova 23, 76-84.

Swiecicki, T., Wilcockson, P., Canham, A., Whelan, G., Homann, H., 1995. Dating, correlation and stratigraphy of Triassic sediments in the West Shetlands area. In: Boldy, S.A.R (Ed.), Permian and Triassic Rifting in Northwest Europe: Geological Society Special Publication, 91, pp. 57-85

Szurlies, M., 2007. Latest Permian to Middle Triassiccyclo-magnestratigraphy from the Central European Basin. Germany: implications for the geomagnetic polarity timescale. Earth Planet Sci. Lett. 261, 602-619.

Tabor, N.J., Montañez, LP., 2002. Shift in late Paleozoic atmospheric circulation over western equatorial Pangea: insights from pedogenic mineral $6^{\mathbf{1 2}} \mathrm{O}$ compositions. Geology 30 (12), 1127-1130.

Thorne, C.R., Russel, A.P., Alam, M.K., 1993. Planform pattern and channel evolution of the Brahamaputra River, Bangladesh. In: Best, J.L., Bristow, C.S. (Eds.), Braided Rivers: Geological Society Special Publication, 75, pp. 257-276.

Twitchett, R.J., 1999. Palaeoenvironments and faunal recovery after the endPermian mass extinction. Palaeogeography, Palaeoclimatology, Palaeoecology 154, 27-37.

Ulicný, D., 2004. A drying-upward aeolian system of the Bohdasin Formation (EarlyTriassic), Sudetes of NE Czech Republic: record of seasonality and long-term palaeoclimate change. Sedimentary Geology $167,17-39$.

Uysal, LT., Zhao, J.-X., Golding, S.D., Lawrence, M.G., Glikson, M., Collerson, K.D. 2007. Sm-Nd dating and rare-earth element tracing of calcite: implications for fluid-flow events in the Bowen Basin, Australia. Chemical Geology 238 , 63-71.

Vargas, H., Gaspar-Escribano, J., Iópez-Gómez, J., van Wees, J.-D., Cloetingh, S., De la Horra, R., Arche, A., 2009. A comparison of the Iberian and Ebro Basins during the Permian and Triassic, eastern Spain: a quantitative subsidence modelling ap proach. Tectonophysics $474,160-183$

Wignall, P.B., 1990. Observations on the evolution and classification of dysaerobic com munities. In: Miller, W. (Ed.), PaleocommunityTemporal Dynamics. The Long-term Development of Multispecies Assemblages: Paleontological Society Special Publication, 5, pp. 99-111.

William, P.F., Rust, B.R., 1969. The sedimentology of a braided river. Journal of Sedimentary Petrology 39, 649-679.

Wilson, LG., 1973. Ergs. Sedimentary Geology 10, 77-110.

Woods, A.D., 2005. Paleoceanographic and paleoclimatic context of Early Triassic time. Comptes Rendus Palevol4, 463-472.

Woods, A.D., Bottjer, D.J., Mutti, M., Morrison, J., 1999. Lower Triassic large sea-floor carbonate cements: their origin and a mechanism for the prolonged biotic recovery from the end-Permian mass extinction. Geology 27, 645-648. 